\title{
Recent Progress in Studies of Magnetospheric Storms and Substorms ${ }^{\dagger}$
}

\author{
S.-I. AKASOFU* and Y. KAMIDE** \\ ${ }^{*}$ Geophysical Institute, University of Alaska, Fairbanks, Alaska, U.S.A. \\ **Kyoto Sangyo University, Kamigamo, Kita-ku, Kyoto, Japan
}

(Received May 17, 1980; Revised June 3, 1980)

\begin{abstract}
We have made various degrees of progress during the last two years in the areas covered by Topic III-6, Magnetic Storms and Substorms, including Aurora-Magnetospheric Relations. The finding of the $V$-potential structure above the auroral oval was certainly an important milestone in the history of magnetospheric research. The relationship between field-aligned currents and ionospheric currents has become increasingly clear during the last few years. Extensive attempts have been made to understand how the solar wind couples its energy to the magnetosphere and to find the expression for the rate of input energy from the solar wind to the magnetosphere. On the basis of this progress, a new model of the solar wind-magnetosphere relationship has begun to emerge.

The interpretation of observed magnetotail phenomena is still very confusing. Some of the problems associated with this confusion are discussed. Decisive observations to identify the basic processes associated with the "injection" of ring current particles have not been made. However, the finding of $\mathrm{O}^{+}$ions in the ring current belt was an exciting event during the last two years.
\end{abstract}

\section{Introduction}

There is no doubt that magnetospheric substorms can be considered to be, in many aspects, the most basic dynamical process occurring in the magnetosphereionosphere system. This is clearly demonstrated in recent two books by AKASOFU (1977) and NisHIDA (1978) which present details of substorm processes and their physical interpretations. Over the last two years, which this review paper attempts to cover, there has been a considerable amount of work done in the areas of magnetospheric storms and substorms. In this report, we describe some of the highlights of our progress as well as some of the crucial problems which will hopefully be clarified during the next several years.

+ Presented as a Reporter Review for Division III of IAGA at the IUGG/IAGA General Assembly in Canberra, Australia, December 1979. 


\section{Definition of Substorm}

Perhaps the most exciting topic that must be mentioned is a small-group workshop held in Victoria, Canada in August of 1978. Nine magnetospheric physicists active in the area of substorm research met on campus of the University of Victoria for three days to attempt to reach a concensus on the definition of substorms.

To understand physical processes which are responsible for magnetospheric substorms, one must know the time sequence of various signatures associated with substorms. This timing is especially important for the establishment of causeand-effect relationships among various complex phenomena occurring during substorm activity. One of the most basic goals of our study is to understand under what conditions a substorm begins.

The original definition of substorm onset was 'the sudden brightening of an equatorward aurora near mignight' by AKASOFU (1964). In extending this substorm concept, AKASOFU et al. (1965) showed that the polar magnetic signature of substorm onset was a sudden intensification of the westward electrojet right beneath that brightening auroral arc. It was then suggested that the sudden decrease of the auroral zone $H$ component magnetic field near midnight can also be used as a signature of substorm onset. Later, other phenomena were also correlated with the $H$ onset and found to undergo sudden changes as well. However, it has become clear, unfortunately, over this decade of research, that these different substorm manifestations do not always provide the same substorm timing. As a result, different groups have used different signatures to define the time frame of substorms. At the present time, many individuals and groups are involved in a study of processes which constitute magnetospheric substorms. One of the major problems in this research is to synthesize the relationship among these processes resulting from the solar wind-magnetosphere interaction.

However, there has been no agreed definition of a magnetospheric substorm. Further, many researchers are not familiar with the different techniques for timing and ordering various substorm phenomena. The intercalibration of the available signatures for substorms is urgently needed. The main purpose of the Victoria workshop was to alleviate these problems by summarizing what we have really established during the last twenty years of substorm research and by making clear what the source of the controversy is. The final document describing the decisions reached by all nine participants is published by RosTOKER et al. (1980).

The agreed definition of a magnetospheric substorm is as follows: A magnetospheric substorm is a transient process initiated on the nightside of the earth, in which a significant amount of energy derived from the solar wind-magnetosphere interaction is deposited in the auroral ionosphere and in the magnetosphere.

This substorm concept was further extended to an operational definition in 
terms of measured parameters commonly available to researchers, as follows: A substorm is an interval of enhanced energy dissipation during which the strength of the auroral electrojets increases from and returns to the background level. During this interval there may be a sequence of intensifications of the electrojet, each associated with the generation of a $\mathrm{Pi} 2$ burst and a westward traveling surge. As the substorm develops, the region of disturbed aurora near midnight expands poleward and westward, reaching eventually a maximum latitude and beginning to recover. This working definition differs somewhat from the original definition of the auroral substorm by AKASOFU (1964). He established the framework upon which the magnetospheric substorm phenomenon has been described to date.

The followings are some other items that are agreed by the nine authors:

1) There is no inherent difference between physical processes responsible for weak and intense substorms.

2) If the interplanetary magnetic field (IMF) has a significant northward component for an interval of time greater than several substorm time constants; the magnetosphere approaches a state of lowest activity; the probability of substorm occurrence approaches zero.

3) As the IMF turns away from this state, there can be an interval of enhanced convection prior to the first substorm expansion. Substorms can be triggered during periods in which the IMF has either a northward or a southward component.

4) Substorm onset is signalled by the brightening of an arc located near the equatorward boundary of the oval of discrete auroras.

5) For the present time magnetograms from auroral oval and low latitude observatories can be used to define substorm onsets, if used with caution.

It may also be important to note that the "Victorian Nine" agreed unanimously that a substorm is associated with diversion of the cross-tail current to the polar ionosphere.

\section{Relationship between Substorms and Solar Wind Parameters}

There have been a large number of studies which have attempted to correlate geomagnetic indices with solar wind parameters. Table 1 summarizes most of the past work of such correlation studies.

The general practice in this study has been (i) to choose or devise a particular geomagnetic index and (ii) to attempt to find a solar wind parameter or a specific combination of two or more of them. As the solar wind parameters, most workers have chosen the solar wind speed $V$ and the density $n$, the interplanetary electric field $E$, the interplanetary magnetic field $\boldsymbol{B}\left(B_{x}, B_{y}, B_{z}\right)$ and the variance ( $\left.\sigma\right)$ of these quantities. As Table 1 shows, for a chosen geomagnetic index, there is a particular solar wind quantity or a combination of them which correlates with it: 
Table 1. List of the correlation studies between geomagnetic indices and solar wind parameters.

\begin{tabular}{|c|c|c|c|}
\hline Author(s) & $\begin{array}{l}\text { Geomagnetic } \\
\text { (time resolut }\end{array}$ & index & $\begin{array}{l}\text { Relation with solar } \\
\text { wind parameters }\end{array}$ \\
\hline SNYDER et al. (1963) & $\sum K p$ & $(24 \mathrm{hr})$ & $\sum K p=(V-330) / 8.44$ \\
\hline OLHERT (1968) & $\sum K p$ & $(24 \mathrm{hr})$ & $\sum K p=(V-262) / 6.3$ \\
\hline BALLIF et al. (1969) & $K p$ & $(3 \mathrm{hr})$ & $K p=9\left\{1-\exp \left(\frac{-\sigma B_{T, N}-0.35}{7.70}\right)\right\}$ \\
\hline ARNODY (1971). & $A E$ & $(1 \mathrm{hr})$ & $\begin{aligned} A E= & -0.26\left(\sum B_{s} \tau\right)_{0}-0.91\left(\sum B_{s} \tau\right)_{1}, \\
& -0.33\left(\sum B_{s} \tau\right)_{2}+0.12 P_{0}\end{aligned}$ \\
\hline BROBOV (1973) & $K p$ & $(3 \mathrm{hr})$ & $K p=f\left(V, B_{z} \Delta B_{z}\right)$ \\
\hline GARRETT et al. (1974) & $a p, A E$ & $(1 \mathrm{hr})$ & $a p, A E \propto C_{1}+C_{2} V\left\langle B_{s}\right\rangle+C_{3} V \sigma$ \\
\hline $\begin{array}{l}\text { MURAYAMA and HAKAMADA } \\
\text { (1975) }\end{array}$ & $A E$ & $(1 \mathrm{hr})$ & $A E=C B_{s} V^{2}$ \\
\hline BURTON et al. (1975) & Dst & (2.5 min) & $\frac{\mathrm{d}}{\mathrm{d} t} D s t_{0}=F(E)-a D s t_{0}$ \\
\hline CROOKER et al. (1977) & $A p$ & & $A p=3.5 \times 10^{-5}\left|\bar{B}_{z}\right| \bar{V}^{2}-1.9$ \\
\hline SVALGAARD (1977) & $a m$ & $(3 \mathrm{hr})$ & $\begin{aligned} a m= & 6.6 q(f, \alpha)\left\{\frac{B V_{0}}{21}\right\}\left[\frac{n V_{0}^{2}}{105}\right]^{1 / 3} \\
& \times \frac{1.157}{\left(1+3 \cos ^{2} \psi\right)^{2 / 3}}\end{aligned}$ \\
\hline $\begin{array}{l}\text { Perreault and AKasofu } \\
\text { (1978) }\end{array}$ & $A E, D s t$ & $(1 \mathrm{hr}, 6 \mathrm{~min})$ & $\widetilde{U}_{T}=V B^{2} \sin ^{4}(\theta / 2) l_{0}^{2}$ \\
\hline MAEZAWA (1979) & $A L, A U, a m$ & $(1 \mathrm{hr})$ & $\begin{array}{l}A L \propto B^{0.85} V^{2.08}(\sin \theta)^{0.54} \\
A U \propto B^{0.67} V^{1.15}(\sin \theta)^{0.34} \\
a m \propto B^{1.03} V^{2.34}(\sin \theta)^{0.37} n^{0.2}\end{array}$ \\
\hline HOLZER and SLAVIN (1979) & $A L$ & $(1 \mathrm{hr})$ & $\begin{array}{l}\text { Rate of erosion } \\
\frac{\mathrm{d} \phi_{e}}{\mathrm{~d} t}=0.2\left(1.9 \times 10^{10} \mathrm{~cm}\right) B_{s} V_{z w}(\mathrm{~km} / \mathrm{sec}) \\
\text { Rate of return } \\
\frac{\mathrm{d} \phi_{r}}{\mathrm{~d} t}=1.8 \times 10^{10} A L(\gamma)\end{array}$ \\
\hline MURAYAMA (1979) & $A L$ & $(1 \mathrm{hr})$ & $A L=60\left(B_{s}+0.5\right) V^{2} \cdot F\left(X, B_{z}\right) n^{0.13}$ \\
\hline
\end{tabular}

Note: For details of the expressions and definitions of each notation, see the referenced papers.

An important point to consider here is the purpose of such a study. One expects that the finding of a high correlation between a geomagnetic index and a solar wind quantity would lead to a better understanding of physical processes involved in the solar wind-magnetosphere interaction. If this is indeed the basic motivation of such a study, one must be clear about what the chosen geomagnetic index really represents. Let us take for example, the $K p$ index. What does this semi-logarithmic index, from 0 to 9 , physically represent? This question may be more difficult to answer than to find the correlation. In fact, there are perhaps only a few workers who know exactly how the $K p$ index is produced. Similarly, what does the daily sum of eight semi-logarithmic $K p$ numbers $\left(\sum K p\right)$ represent? 
Similar questions can also be raised to all correlation studies which choose the $C 9$, $A p$, am indices; note that these indices are derivative indices from the $K p$ index. The present reporters believe that these indices are intended to be a very qualitative measure of geomagnetic activity and are not intrinsically compatible with basic physical quantities, such as $V, B, n$, etc.

In this respect, the choice of the auroral electrojet indices $A E, A L$, and $A U$ have an advantage compared with the $K p$ index, since it is the magnetic field intensity of the auroral electrojets. However, one must also be cautious in using these indices since the current intensity depends both on the electric field and the conductivity in the ionosphere. Therefore, even if a high correlation is obtained between the $A E$ index and a particular combination of solar wind parameters, it is not necessarily a simple matter to find the chain of processes involved in the solar wind-magnetosphere interaction which relates the $A E$ index with that particular combination of the solar wind parameters. As mentioned earlier, this may be a more difficult problem than finding the correlation. In dealing with a geomagnetic index, one should also be aware of its accuracy. The fidelity of the $A E$ index as a substorm index is unlikely to be more than $70 \%$, so that there is no reason to attempt to find a combination of solar wind parameters which provides more than $70 \%$ of correlation. The best way to learn about the fidelity of any index is to produce it oneself.

Different geomagnetic indices have a high correlation with different combinations of solar wind parameters (e.g., MAEZAWA, 1978). Those differences are not discrepancies or disagreements. The $K p$ and the $A E$ indices are not the same measure of geomagnetic activity. It should be noted that BURTON et al. (1975) examined the relationship between the ring current production rate estimated from the $D_{s t}$ index and the interplanetary electric field $E$. This is certainly a better approach than a simple correlation study.

Perreault and AKasofu (1978) attempted to correlate the total energy dissipated in the magnetosphere-ionosphere system with the IMF by taking somewhat a different way of estimating the energy rate from the others. They determined first the total energy consumption rate $\bar{U}_{T}(\mathrm{erg} / \mathrm{sec})$ of the magnetosphere by using the Dst and $A E$ indices. Here,

$$
\begin{aligned}
& \bar{U}_{T}=\bar{U}_{R}+\bar{U}_{J}+\bar{U}_{A} \\
& \bar{U}_{R}=4.0 \times 10^{20}\left(\frac{\partial D s t}{\partial t}+\frac{D s t}{\tau_{R}}\right) \quad \mathrm{erg} / \mathrm{sec} \\
& \bar{U}_{J}=A E(\gamma) \times 10^{15} \mathrm{erg} / \mathrm{sec} \\
& \bar{U}_{A}=A E(\gamma) \times 1.5 \times 10^{14} \mathrm{erg} / \mathrm{sec} .
\end{aligned}
$$

After determining the total energy consumption rate $\bar{U}_{T}$ (erg/sec), their problem was reduced to finding a combination of the solar wind parameters which has the dimension of $(\mathrm{erg} / \mathrm{sec})$. The simplest combinations are $\rho V^{3}$ and $V B^{2}$. 
Since it has long been known that $\rho V^{3}$ has little correlation with $\bar{U}_{T}$, the obvious choice is then $V B^{2}$. Perreault and AKasofu (1978) found that the following expression has a high correlaton $(\sim 70 \%)$ with $\bar{U}_{T}$ :

$$
\varepsilon=V B^{2} \sin ^{4}\left(\frac{\theta}{2}\right) l_{0}^{2}
$$

where

$\theta=$ the polar angle of the IMF projected on the dawn-dusk meridian,

$l_{0}=$ constant $\left(\simeq 7 R_{E}\right)$.

It is also important to note that KAN et al. (1980) showed that the above parameter $\varepsilon$ can be identified as the dynamo power delivered from the solar wind to the magnetosphere. This identification not only provides a theoretical basis for the energy coupling function, but also constitutes an observational verification of the solar wind-magnetosphere dynamo theory. Moreover, it is interesting to note that the onset, expansive phase, the maximum epoch and the recovery phase of magnetospheric substorms may be much more tightly controlled by the solar wind than previously thought (see SwIFT, 1980).

AKASOFU (1979b) has shown by using hourly-value $A E$ indices and solar wind parameters that there is a higher correlation coefficient between the $A E$ index and $\varepsilon$ than that between $A E$ and just $B_{z}$. Some question has recently been raised by several workers about the results that substorm activity and substorm energy are proportional to $V B^{2}$. By using a 10 years' data set of $3 \mathrm{hr}$ averages of hourly values, MAEZAwA (1978) has shown statistically that the $A L$ index is proportional to $B V^{2}$ while $A U$ is proportional to $B V$. Since the $A L$ magnitude is generally larger than the $A U$ magnitude, the $A E$ index $(=A U+|A L|)$ is related mainly to $B V^{2}$, not to $B^{2} V$. HaKamada et al. (1979) and Murayama et al. (1980) have reached similar conclusions. Such differences are not discrepancies or disagreements. One can easily see that the quantity $B V^{2}$ has the dimension of current $I_{2}$ and that $A E$ is proportional to $I$. Thus, $A E$ should correlate best with $B V^{2}$, while $\varepsilon(\mathrm{erg} / \mathrm{sec})$ should correlate with $V B^{2}$ (erg/sec).

It must also be noted, in attempting to evaluate the role of the reconnection theories in understanding substorm processes and the solar wind-magnetosphere coupling, that the dayside reconnection alone does not seem to couple the solar wind energy into the magnetosphere. In the region between the northern and southern cusps, the Poynting vector is directed outward across the magnetopause. The Poynting vector is directed inward across the magnetopause only on the downstream side of the cusps. Some of the recent ISEE/A and /B observations indicate that the basic process occurring on the magnetopause is transient in nature (RUSSELL and ElPHIC, 1979). It may well be that plasma instabilities at the magnetopause are so intense that the gyro-motions of solar wind particles and magnetospheric 
plasma particles are almost always interrupted there. Therefore, the frozen-in-field concept may not be applicable in the magnetopause transition zone, nor perhaps in its immediate vicinity.

The last two years saw continued progress in the study of the role of the IMF in controllng the size of the auroral oval or the polar cap. During a prolonged period $\left(>12 \mathrm{hr}\right.$ ) of a large northward total field (i.e., a strong positive $B_{z}$ ), the auroral oval contracts asymptotically to its minimum size. This condition of the magnetosphere is called the 'ground state', and there is little substorm activity along the minimum size oval (KAMIDE et al., 1977). This is the only period when the magnetosphere is in the steady state.

The auroral oval tends to expand immediately as soon as the IMF vector changes from almost a true northward-directed state (ZVEREV et al., 1978; DANDEKAR and PIKe, 1978). Horwitz and AKasofu (1977) showed that the latitude of the dayside cusp shifts progressively equatorward after the $B_{z}$ component becomes negative. Electric field variations in the vicinity of the auroral oval were examined by HoRwitz et al. (1978) who found that the southward turning of the IMF $B_{z}$ component causes a rapid expansion of the auroral oval.

Holzer and Slavin (1978) showed that the amount of magnetic flux transfer from the dayside magnetopause can be equated with the return flux measured in terms of the substorm $A L$ index. It must be noted in this connection that EATHER et al. (1979) suggested that any erosion of dayside magnetic flux is not a direct result of southward turning of the IMF, but the cusp position is intimately related to substorm timing and intensity.

\section{Substorm Time Sequence}

Geomagnetic data have provided valuable means in monitoring magnetospheric processes at remote locations on the earth's surface. The ground-based observations have several advantages over space observations by rockets and satellites. There are relatively a large number of observatories on the ground which continuously measure magnetic and electric fields and auroras, while only a few satellites are in the magnetosphere at any one time. Thus, for many magnetospheric physicists, it has increasingly become the common practice to use ground-based data in determining the onset time and the phases of magnetospheric substorms.

The timing of substorm sequence is not a trivial problem in establishing the cause-and-effect relationship among various phenomena occurring during the course of substorms. The use of ground magnetograms to determine the onset time of substorms was critically reviewed by MCPHERRON (1978). Since the sudden growth of the westward electrojet in the midnight sector is one of the dominant features of polar substorms, a sudden negative deviation near the auroral breakup can be an important tool of identifying the onset. However, this method requires 
great care, particularly when data from a limited set of observatories are utilized. The pitfalls lie in the fact that the sudden onset thus determined at one station is often delayed 15-20 minutes relative to the onset at other stations. GUPTA and LOOMER (1979) have recently noted that the presently available $A E$ indices may be in error at times $150 \mathrm{nT}$ or more, since the present $A E$ network of observatories does not have enough latitudinal width to monitor properly the electrojet activity. This means that one must be cautious in using the $A E$ indices as the measure of the auroral electrojet.

Another tool which has been of frequent use in inferring the substorm onset time and the intensity of the auroral electrojet is the temporal change of the latitudinal profile of all three components as developed by Rostoker and his colleagues. By comparing observed profiles and model profiles, a number of characteristics of the substorm electrojet have been found. However, even though an accurate location of the electrojet is deduced from the latitudinal profiles, similar time delays are expected to occur in the east-west direction, since the electrojet expands and contracts in a very complicated fashion in the longitudinal direction. The network of the two-dimensional arrays in Canada developed by Gough and in Scandinavia by Untiedt have been used to monitor the distribution of the auroral electrojets as well as field-aligned currents, which represent the divergence of the ionospheric currents (BANNISTER and Gough, 1977, 1978; UNTIEDT et al., 1978). Studies of magnetic and auroral data from several other IMS meridian chains are strongly desired.

The determination of the substorm onset on the basis of the $D$ component magnetograms was made by SHIRMAN et al. (1978) who noted that although characteristic features in the $H$ component do not apparently coincide along the meridian chain which they used, the $D$ component is not subject to any timing difference. This may be explained by assuming that the main part of the $D$ perturbations result from the field-aligned current flowing in a distant place, while the $H$ component is influenced much more closely by local structures of the ionospheric currents than by the field-aligned currents.

Considerable attention has been given to magnetic positive bays in the $H$ component in middle and low latitudes as a good indicator of the onset time and magnitude of substorms. It has been earlier suggested that such positive bays can be interpreted as the magnetic effect of the net field-aligned current flowing into and out of the polar ionosphere. We note in this respect that by this method, we can detect only intense substorms in which the mid-latitude effect is larger than several nT. The "Victorian Nine" agreed that insofar as identification of substorm onsets from middle and low latitude magnetograms is concerned, the $D$ component generally provides the best indicator of the earliest detectable onset time. The $H$ component signature depends on the positon of the observatory with respect to the meridian of the auroral electrojet. 
There are also several other topics of important findings which are associated with the onset of auroral substorms. First, Pellinen and HeIKkILA (1978) reported observations of an auroral fading which occurs a few minutes before the main breakup. In a typical sequence referring to a meridian chain of all-sky cameras, an auroral backscatter radar and micropulsation activity, an auroral arc moves equatorward well before the substorm expansion, then fading comes just before the breakup. It was suggested that the fading phenomenon is an indication of the behaviour of the electric field in the magnetosphere, which is diminished locally in the vicinity of the fading arc. KAWASAKI and RosTOKER (1979) have presented data from a magnetometer array with associated all-sky camera coverage and found that in the late evening sector, the sudden $H$ decrease did not coincide with brightening of auroras. A significant enhancement of the westward electrojet near the Harang discontinuity occurred a few minutes prior to the development of the surge in the field of view of the array.

The second topic of interest is the location of auroral arcs near substorm onsets. Using fortuitous polar passes of the ISIS-2 satellite which provides auroral imagery and particle data, LUI and BURRows (1978) have suggested that the substorm triggering process occurs on closed field lines well within the outer and inner edges of the plasma sheet. This finding is very important in understanding of the substorm onset processes.

\section{Magnetotail Observations}

There have been a large number of conflicting reports on magnetic field variations and plasma flows in the magnetotail during magnetospheric substroms. The focal point of conflict is whether or not the present data set can confirm reconnection theories in the plasma sheet in conjunction with substorm onset. It is fair to say that the results are still controversial and very confusing. One of the problems in this topic seems to result from the tendency that only the $B_{z}$ component was used to discuss the dynamics of the magnetotail associated with substorm processes. In fact, the two components $\left(B_{x}, B_{z}\right)$ are not yet enough, and the $B_{y}$ component is often as large as the other two components and is highly variable with time. After all, the magnetic field vector has the three components!

The past analyses of plasma flow have also been found to be inadequate. In the past, it was tacitly assumed that the flow was only an $(E \times B)$ drift motion in the magnetotail. It was LUI et al. $(1977,1978)$ who pointed out that a high speed flow has often a large component along magnetic field lines. If this is the case, the basic physics associated with motions of plasma along and perpendicular to magnetic field lines may be quite different.

Future studies of magnetotail data should be based on a careful analysis of the three components of $\boldsymbol{B}\left(B_{x}, B_{y}, B_{z}\right)$ and $V\left(V_{x}, V_{y}, V_{z}\right)$, in addition to all basic 
plasma characteristics. If such an elementary practice would be ignored in the future, the present confusion may continue even with high quality data from the ISEE satellites. Caution must be also exercised in identifying particular locations within the magnetotail where particular signatures for the substorm dynamics under study are observed. For example, magnetic variations in the tail lobe and near the neutral sheet within the plasma sheet are different even at the same $L$ distance, and flow vectors of the tail plasma are variable depending on the location of the satellite observations.

It is also important to consider at this point what reconnection theories attempt to establish in the studies of magnetospheric dynamics. The acceleration of auroral particles is now found to take place mainly at a distance of 1.5-2.0 earth radii above the auroral oval. If the potential drop along the field lines there can really be as large as $5 \mathrm{keV}$, it may not be necessary to find major acceleration processes of auroral particles in the distant plasma sheet, although it seems likely that the reconnection process or disruption in the tail current in the plasma sheet relates to the generation of field-aligned currents.

\section{Ring Current Formation}

In spite of extensive studies in the past, the formation of the ring current belt has not been clearly understood. First of all, as WiLliams (1978) pointed out, we have not identified the positive ions which constitute the main part of the ring current belt, so far only the high energy tail and the low energy end of the spectrum. Secondly, there has been no decisive observation to indicate that those ions, as well as hot electrons, are "injected" from the plasma sheet or are "locally accelerated", either along the geomagnetic field lines or in the equatorial plane. Therefore, the so-called "injection" process remains at present unveiled. This must be a frustrating experience for those who have worked in this particular area. Even if the dispersion observation is fully used, a single satellite observation would not be able to solve the problem. Well-planned, multi-satellite observations may be needed to reduce the large number of possibilities. A well-coordinated observation of plasma sheet particles and electric fields, at distances between 6 and 10 earth radii by more than two satellites, is needed to "trace" plasma particles. This effort should also be aided by modeling studies.

One of the highlights in the study of the ring current belt during the last two years is the finding of $\mathrm{O}^{+}$ions, both above the auroral oval (JoHnson et al., 1975) and in the ring current belt (BALSIGER et al., 1979). At times, the flux of $\mathrm{O}^{+}$ions can be greater than that of protons. It is of great interest to examine the energy density of $\mathrm{O}^{+}$in comparison to the total energy density of the ring current belt. It is quite likely that $\mathrm{O}^{+}$ions are of ionospheric origin. The $V$-shaped potential structure can accelerate $\mathrm{O}^{+}$ions upward, in addition to the downward acceleration 
of electrons. However, there are at least two problems to be solved in understanding the formation of the ring current belt of $\mathrm{O}^{+}$ions. First of all, $\mathrm{O}^{+}$ions must be trapped in the belt by changing drastically the initial pitch-angle distribution. Secondly, since the auroral field lines are expected to cross the equatorial plane at a geocentric distance of 10 earth radii or greater, one must find the transport mechanism for $\mathrm{O}^{+}$ions to be convected to a geocentric distance of 3-6 earth radii. A highly transient and large electric field may be required for the transport process.

\section{Electric Field Observations}

The electric field observations during the last two years have made the most remarkable progress, not only in terms of the elucidation of the large-scale convection pattern over the polar region, but also in terms of revealing the $V$-shaped potential structure.

It is noteworthy in particular that four different types of observations have contributed in revealing the $V$-shaped potential structure. They are direct electric field observation by the S3-3 satellite (MozER et al., 1979), auroral particle observations by the same satellite (MIZERA and FenNell, 1977), $B a$ shape-charge injections by rockets (WeSCOTT et al., 1978) and $T V$ observations of the shear motion of auroral arcs (HALlinan, 1969). Thanks to those who contributed to these studies.

It has been suggested that this particular potential structure is a double layer. However, there are several different views among theorists about the role of the double layers in causing the potential drop. It has also been suggested that the potential drop is caused by an electrostatic shock and anomalous resistivity. Certainly, the finding of the potential structure has stimulated a number of theorists to work on this interesting problem. However, it is too early to identify the nature and cause of the formation of such a potential structure, except that it is quite likely that field-aligned currents are closely related to this phenomenon. Therefore, the generation mechanism of the field-aligned currents from the solar wind-magnetosphere dynamo is one of the most important future problems in magnetospheric physics.

The finding of the potential structure has profound implications in studying magnetospheric processes. First of all, one can no longer map magnetospheric electric fields to the ionosphere along geomagnetic field lines, or vice versa, by assuming that the field lines are equipotential lines. In fact, since the electric field associated with the $V$-shaped potential is very large $(1 \mathrm{mV} / \mathrm{m})$, compared with a typical ionospheric electric field $(\sim 20 \mathrm{mV} / \mathrm{m})$, and cannot be seen in the ionosphere (but will be seen in the plasma sheet), one would expect that the electric field pattern in the magnetosphere is considerably different from what one would expect from the ionospheric field pattern. Thus, the coupling between the magnetosphere and the ionosphere is not perfect. 
It is interesting to recognize that the aurora is a manifestation of this imperfect coupling between the magnetosphere and the ionosphere, since the potential drop accelerates auroral particles. Further, since there is an electric field parallel to the magnetic field, one can no longer identify motions of individual magnetic field lines. Thus, the frozen-in-field concept does not hold in the magnetosphere. Indeed, the presence of the aurora is a manifestation of the breakdown of the classical frozen-infield concept which we have taken for granted for a long time.

It was mentioned earlier that the presence of a large potential drop of the order of $5 \mathrm{keV}$ above the auroral oval indicates that the major portion of auroral particle acceleration takes place a little above the ionosphere, not in the plasma sheet.

\section{Substorm Current Systems}

During the last two years, good progress was made in the study of threedimensional current systems during magnetospheric substorms, in particular, the relationship between field-aligned currents and ionospheric currents, the convection electric field, discrete and diffuse auroras and auroral electron spectra. Such a variety of observations have finally begun to converge in providing a self-consistent model of the magnetosphere-ionosphere coupling.

Numerical simulations of ionospheric electric fields and currents in relation to field-aligned currents have been conducted by several groups, such as NoPPER and Carovillano (1978), Nisbet et al. (1978), MaeKawa and Maeda (1978), and KAMIDE and MATSUSHITA (1979). These works proved the simulations to be a powerful tool in unveiling physical processes occurring during substorms in the ionosphere-magnetosphere system. This part will be reported in more detail in Division III, Topic 1 (RostoKeR, 1980).

\section{Summary}

It may be worthwhile to describe briefly a newly emerging model of the solar wind-magnetosphere interaction on the basis of the progress made during the last two years.

Let us consider the situation in which the solar wind-magnetosphere dynamo power increases from $\sim 10^{17} \mathrm{erg} / \mathrm{sec}$ to $\sim 10^{20} \mathrm{erg} / \mathrm{sec}$. The magnetosphere is quite insensitive to $\varepsilon<10^{17} \mathrm{erg} / \mathrm{sec}$. As $\varepsilon$ increases from $\sim 10^{17} \mathrm{erg} / \mathrm{sec}$ to $\sim 10^{18} \mathrm{erg} / \mathrm{sec}$, the increased power generation is manifested by various phenomena, such as enhanced convection in the polar cap (thus enhanced field-aligned currents) and an enhanced magnetotail current. Note, however, that there is little energy accumulation in the magnetosphere by this increase, since the Joule heat production in the polar cap dissipates most of the generated power. 
As $\varepsilon$ reaches $\sim 10^{18} \mathrm{erg} / \mathrm{sec}$, an auroral arc in the midnight sector suddenly brightens, indicating the onset of a magnetospheric substorm. It may be interpreted that an increasing intensity of field-aligned currents reaches the level that the resulting potential drop in the $V$-shaped potential structure becomes $\sim 1 \mathrm{keV}$, so that the accelerated auroral particles can reach the $E$ region of the ionosphere.

As $\varepsilon$ increases further $\left(>10^{18} \mathrm{erg} / \mathrm{sec}\right)$, the substorm intensifies. The power generated by the dynamo is now partly dissipated in the ionosphere by producing the Joule heat and also by auroral particles. Another part is consumed in building up the ring current belt.

An interesting phenomenon takes place as $\varepsilon$ reaches $\sim 10^{19} \mathrm{erg} / \mathrm{sec}$. The ring current begins to grow abnormally and the Joule heat production rate tends to level off. A further increase of $\varepsilon$ does not increase significantly the Joule heat production rate.

It may be speculated that the potential drop in the $V$-shaped potential structure becomes large enough so that the potential difference across the polar cap can no longer increase. At the same time, the $V$-shaped potential structure accelerates a large number of $\mathrm{O}^{+}$ions toward the equatorial plane. These $\mathrm{O}^{+}$ions may become a significant part of the ring current particles.

As $\varepsilon$ begins to decrease, the substorm intensity begins also to decline; the recovery phase begins. An important point is that there is a high correlation between solar wind parameters and substorm activity indicating that the solar wind is primarily responsible for gross features of both the growth and decay of magnetospheric substorms. It should be noted that this does not mean that the onset, expansive phase characteristics and the onset of the recovery phase, etc. may all not be determined by magnetospheric time constants. This is because the substorm time constants are less than 1 hour but most of the studies of the relationship between the solar wind parameters and geomagnetic indices are based on hourly average values, and because the growth and decay of substorms with finer time scale (like 5 minutes) cannot be expressed by any of the available indices.

\section{Aiming toward the OPEN Era}

A few comments may be in order in preparing us for the OPEN era which will be one of the major magnetospheric projects in the next decade.

\subsection{Magnetic tape output for the AE stations}

First of all, we must drastically improve the production procedure of the $A E$ index. It is suggested that all $A E$ stations be equipped with a magnetometer which can provide magnetic tapes as the output recording. We should start this conversion now, rather than all at once in 1985. Unless such an effort is made, magnetometers may become an obsolete instrument in magnetospheric studies (not 
because the data are not useful, but because of time-consuming data handling).

\subsection{New magnetometer networks}

The IMS meridian chains of magnetometers have demonstrated that such a systematic data gathering is indeed a powerful tool in studying magnetospheric processes. A network of magnetometers should be carefully planned for the OPEN era; note that this does not necessarily mean an increase of the total number of magnetometers. It may also be necessary to construct unmanned stations in order to avoid serious gaps in the network. An international effort may be useful in this venture by gathering various experiences each group has had on the power supply, heating systems, etc.

The work reported here was supported in part by grants from the U. S. National Science Foundation, Atmospheric Sciences Section, ATM-77-26522 and ATM-79-02953, and in part by the Ministry of Education of Japan under grants 433-7003-364141, -464134, and 433-6003-354127.

\section{REFERENCES}

List of the publications in the area of Topic III- 6 which are published during the last two years. The papers are classified under the following headings.

I. General Reviews

II. Substorm

a. Relationship with the solar wind

b. Onset and theories

c. Distant magnetosphere observations and their theories

III. Plasma Injection

a. Ring current and plasmasphere

IV. Aurora
a. Morphology
b. Field-aligned currents, ionospheric electric fields and currents, and magnetic dis- turbances
c. Acceleration process, precipitation, arc formation
d. Kilometric radiations
e. Radar aurora, absorption
f. Effects on the thermosphere

I. General Reviews

Akasofu, S.-I., Physics of Magnetospheric Substorms, 599pp. D. Reidel Pub. Co., Dordrecht, Holland, 1977.

AKASOFu, S.-I., Magnetospheric substorm, Q.J.R. Astr. Soc., 18, 170-187, 1977.

Mishin, V. M., High latitude geomagnetic variations and substorms, Space Sci. Rev., 20, 621$675,1977$.

Nishida, A., Geomagnetic Diagnosis of the Magnetosphere, 256pp., Springer-Verlag, New York, 1978. Rostoker, G., S.-I. Akasofu, J. Foster, R. A. Greenwald, Y. Kamide, K. Kawasaki, A. T. Y. Lui, R. L. McPherron, and C. T. Russell, Magnetospheric substorms-definition and signatures, J. Geophys. Res., 85, 1163-1668, 1980. 


\section{Substorm}

\section{a. Relationship with the solar wind}

AxASOFu, S.-I., Radial deformation of the solar current sheet as a cause of geomagnetic storms, Planet. Space Sci., 27, 1055-1062, 1979a.

Axasofu, S.-I., Relationship between the growth of the ring current and the interplanetary quanity $\varepsilon$, Planet. Space Sci., 27, 1039-1041, 1979b.

AKASOFU, S.-I., Interplanetary energy flux associated with magnetospheric substorms, Planet. Space Sci., 27, 425-431, 1979c.

AKASOFU, S.-I. and R. P. LEPPING, Interplanetary magnetic field and magnetospheric substorms, Planet. Space Sci., 25, 895-897, 1977.

AleKseyev, I. I., Energy transfer during a magnetospheric substorm, Geomagn. Aeron., 17, 587591, 1977.

AraKI, T., Global structure of geomagnetic sudden commencements, Planet. Slace Sci., 25, 373-384, 1977.

ARNOLDY, R. L., Signature in the interplanetary medium for substorms, J. Geophys. Res., 76, 5189-5201, 1971.

Ballif, J. R., D. E. Jones, and P. J. Coleman, Jr., Further evidence on the correlation between transverse fluctuations in the interplanetary magnetic field and $K p, J$. Geophys. Res., 74, 2289. 2299, 1969.

Bhargava, B. N. and G. K. Rangarajan, Low latitude geomagnetic bays and IMF sector polarity, Planet. Space Sci., 25, 161-164, 1977.

Bobrov, M. S., $K p$ index correlations with solar-wind parameters during the first and second stages of a recurrent geomagnetic storm, Planet. Space Sci., 21, 2139-2147, 1973.

Burch, J. L., Effects of the interplanetary magnetic field on the auroral oval and plasmapause, Space Sci. Rev., 23, 449-464, 1979.

Burke, W. J., M. C. Kelley, R. C. Sagalyn, M. Smiddy, and S. T. Lai, Polar cap electric field structures with a northward interplanetary magnetic field, Geophys. Res. Lett., 6, 21-24, 1979.

Burlaga, L. F. and R. P. Lepping, The causes of recurrent geomagnetic storms, Planet. Spcae Sci., 25, 1155-1160, 1977.

Burton, R. K., R. L. McPherron, and C. T. Russell, An empirical relationship between interplanetary conditions and Dst, J. Geophys. Res., 80, 4204-4214, 1975.

BuYelekova, M., Analysis of the relation of geomagnetic bays to geomagnetic activity and the interplanetary magnetic field in 1968, Geomagn. Aeron., 17, 714-717, 1977.

CAan, M. N., R. L. MCPherron, and C. T. Russell, Characteristics of the association between the interplanetary magnetic field and substorms, J. Geophys. Res., 82, 4837-4842, 1977.

CaAn, M. N., R. L. McPherron, and C. T. Russell, The statistical magnetic signature of magnetospheric substorms, Planet. Space Sci., 26, 269-279, 1978.

Carter, C. L. and K. D. Cole, An important statistical consideration, and the effect of the interplanetory magnetic field on the quiet time variation of the geomagnetic field, Planet. Space Sci., 26, 403-412, 1978.

Crooker, N. U., Dayside merging and cusp geometry, J. Geophys. Res., 84, 951-959, 1979.

Crooker, N. U., J. Feynman, and J. T. Gosling, On the high correlation between long-term averages of solar wind speed and geomagnetic activity, J. Geophys. Res., 82, 1933-1937, 1977.

DANDEKAR, B. S., Relationship between the IMF, the midday gap, and auroral substorm activity, J. Geophys. Res., 84, 4413-4421, 1979.

D'Angelo, N. and C. K. Goertz, An interpretation of Akasofu's substorm parameter, Planet. Space Sci., 27, 1015-1018, 1979. 
Dessler, A. J. and T. W. Hill, Comment on 'On the high correlation between long-term averages of solar wind speed and geomagnetic activity' by N. U. Crooker, J. Feynman, and J. T. Gosling, J. Geophys. Res., 82, 5644-5644, 1977.

EATHeR, R. H., S. B. Mende, and E. J. Weber, Dayside aurora and relevance to substorm current systems and dayside merging, J. Geophys. Res., 84, 3339-3359, 1979.

Garrett, H. B., A. J. Dessler, and T. W. Hill, Influence of solar wind variability on geomagnetic activity, J. Geophys. Res., 79, 4603-4610, 1973.

Haerendel, G., G. Paschmann, N. Sckopke, H. Rosenbauer, and P. C. Hedgecock, The frontside boundary layer of the magnetosphere and the problem of reconnection, J. Geophys. Res., 83, 3195-3216, 1978.

Hakamada, K., T. Aoki, and T. Murayama, Influence of the east-west component of the interplanetary magnetic field on the intensity of the auroral electrojet, Planet. Space Sci., 28, 29-39, 1980.

Hardy, D. H., P. H. ReIFF, and W. J. Burke, Response of magnetotail plasma at lunar distance to changes in the interplanetary magnetic field, the solar wind plasma and substorm activity, J. Geophys. Res., 84, 1391-1401, 1979.

HeIkkIlA, W. J., Criticism of reconnection models of the magnetosphere, Planet. Space Sci., 26, 121-129, 1978.

Henriksen, K., C.S. Deehr, and G. J. Romick, Lunar influence on the occurrence of aurora, J. Geophys. Res., 82, 2842-2846, 1977.

Holzer, R. E. and J. A. Slavin, Magnetic flux transfer associated with expansions and contractions of the dayside magnetosphere, J. Geophys. Res., 83, 3831-3839, 1978.

Holzer, R. E. and J. A. Slavin, A correlative study of magnetic flux transfer in the magnetosphere, J. Geophys. Res., 84, 2573-2578, 1979.

Horwitz, J. L. and S.-I. AkAsofu, On the relationship of the polar cap current system to the north-south component of the interplanetary magnetic field, J. Geophys. Res., 84, 25672572, 1979.

Ivanov, K. G. and N. V. MikerinA, Magnetic extra-storm of August 4-5, 1972, in relation to the hydromagnetic structure of an interplanetary plasma flow from a strong flare, Geomagn. Aeron., 18, 710-712, 1978.

IYEMORI, T., H. MAEDA, and T. KAMEI, Impulse response of geomagnetic indices to interplanetary magnetic field, J. Geomag. Geoelecr., 31, 1-9, 1979.

KAN, J. R. and L. C. LEE, Energy coupling function and solar wind-magnetosphere dynamo, Geophys. Res. Lett., 6, 577-580, 1979.

Kokubun, S., R. L. MCPherron, and C. T. Russell, Triggering of substorms by solar wind discontinuities, J. Geophys. Res., 82, 74-86, 1977.

Kovalevsky, J. V. and T. V. KuzNetsova, Possibility of the investigation of interplanetary shock interaction with the Earth's bow shock, magnetopause and plasmapause by means of a noncoherent response method, Planet. Space Sci., 25, 657-662, 1977.

Kuznetsova, T. V. and M. I. Pudovkin, Peculiarities of solar-wind flow around the magnetosphere and the magnetopause position, Planet. Space Sci., 26, 229-236, 1978.

LASSEN, K., J. R. Sharber, and J. D. Winningham, The development of auroral and geomagnetic substorm activity after a southward turning of the interplanetary magnetic field following several hours of magnetic calm, J. Geophys. Res., 82, 5031-5050, 1977.

Leboeuf, J. N., T. TAJima, C. F. Kennel, and J. M. Dawson, Global magnetohydrodynamic simulation of the two dimensional magnetosphere, in Quantitative Modeling of Magnetospheric Processes, edited by W. P. Olson, pp. 536-556, Am. Geophys. Union, Washington, D.C., 1979. 
Lemaire, J., M. J. RYCroft, and M. Roth, Control of impulsive penetration of solar wind irregularities into the magnetosphere by the interplanetary magnetic field direction, Planet. Space Sci., 27, 47-57, 1979.

MaezaWA, K., Dependence of geomagnetic activity on solar wind parameters: A statistical approach, Solar Terr. Environ. Res. Jpn., 2, 103-121, 1978.

MaezaWA, K., Statistical study of the dependence of geomagnetic activity on solar wind parameters, in Quantitative Modeling of Magnetospheric Processes, edited by W. P. Olson, pp. 436-447, Am. Geophys. Union, Washington, D.C., 1979.

Murayama, T., Principal factors controlling the development of the auroral electrojet, in Magnetospheric Study 1979, edited by T. Obayashi, pp. 196-200, Japanese IMS Committee, Tokyo, 1979.

Murayama, T. and K. Hakamada, Effects of solar wind parameters on the development of magnetospheric substorms, Planet. Space Sci., 23, 75-91, 1975.

Murayama, T., T. Aoki, H. Nakai, and K. Hakamada, Empirical formula to relate the auroral electrojet intensity with interplanetary parameters, Planet. Space Sci., 28, 1980 (in press).

OBERC, P., Magnetospheric tail dynamics and a concept of combined action of viscous drag and magnetic merging, Planet. Space Sci., 27, 1087-1093, 1979.

Olbert, S., Summary of experimental results from M.I.T. detector on IMP-1, in Physics of the Magnetosphere, edited by R. L. Carovillano, J. F. McClay, and H. R. Radoski, pp. 641-659, D. Reidel Pub. Co., Dordrecht, Holland, 1968.

Paschmann, G., N. Sckopke, G. Haerendel, J. Papamastotakis, B. J. Bame, J. R. Asbridge, J. T. Gosling, E. W. Hones, Jr., and E. R. TeCH, ISEE plasma observations near the subsolar magnetopause, Space Sci. Rev., 22, 717-737, 1978.

Perreault, P. and S.-I. Akasofu, A study of geomagnetic storms, Geophys. J. RAS, 54, 547-573, 1978.

Prigancova, A., Stable solar wind and geomagnetic activity, Geomagn. Aeron., 18, 69-70, 1978.

Rezhenov, B. V. and A. I. Fel'Dshteyn, Effect of the fluctuations of the $B_{z}$ component of the interplanetary field on the equatorial electrojet in various intervals of local time, Geomagn. Aeron., 18, 71-74, 1978.

Rezhenov, B. V., V. G. Vorobjev, and Y. I. Feldstein, The interplanetary magnetic field $B_{z}$ component influence on the geomagnetic field variations and on the auroral dynamics, Planet. Space Sci., 27, 699-716, 1979.

Russell, C. T. and R. C. ElPhic, ISEE observations of flux transfer events at the dayside magnetopause, Geophys. Res. Lett., 6, 33-36, 1979.

Russell, C. T., R. L. McPherron, and R. K. Burton, On the cause of geomagnetic storms, J. Geophys. Res., 79, 1105-1109, 1974.

SAto, T. and T. Iujima, Primary sources of large-scale Birkeland currents, Space Sci. Rev., 24, 347-366, 1979.

SchreIBer, H., On the possibility of inferring the interplanetary secter structure from daily variations of geomagnetic ap indices, Planet. Space Sci., 26, 767-775, 1978.

Slavin, J. A. and R. E. Holzer, Empirical relationships between interplanetary conditions, magnetospheric flux transfer, and the $A L$ index, in Quantitative Modeling of Magnetospheric Processes, edited by W. P. Olson, pp. 423-435, Am. Geophys. Union, Washington, D.C., 1979.

Snyder, C. W., M. Neugebauer, and U. R. RaO, The solar wind velocity and its correlation with cosmic-ray variations and with solar and geomagnetic activity, J. Geophys. Res., 68, 63616370, 1963.

SvalgaARD, L., Geomagnetic activity: Dependence on solar wind parameters, in Coronal Holes and High Speed Wind Streams, p. 371, Colorado Associated University Press, Boulder, 1977. 
Swift, D. W., Substorms and magnetospheric energy transfer processes, in Dynamics of the Magnetosphere, edited by S.-I. Akasofu, pp. 327-340, D. Reidel Pub. Co., Dordrecht, Holland, 1979.

Yerkayev, N. V. and V. G. Pivovarov, Model of the interaction of the solar wind with the magnetosphere. Statement of the problem, Geomagn. Aeron., 18, 65-68, 1978.

Zverev, V. L., G. V. Starkov, and Y. I. Feldstein, Influences of the interplanetary magnetic field on the auroral dynamics, Planet. Space Sci., 27, 665-667, 1979.

\section{b. Onset and theories}

Cowley, S. W. H., The effect of pressure anisotropy on the equilibrium structure of magnetic current sheets, Planet. Space Sci., 26, 1037-1061, 1978.

HAYASHI, T. and T. SATO, Magnetic Reconnection: Acceleration, heating and shock formation, J. Geophys. Res., 83, 217-220, 1978.

Heikxila, W. J. and R. J. Pellinen, Localized induced electric field within the magnetotail, J. Geophys. Res., 82, 1610-1614, 1977.

Kamide, Y. and S. Matsushita, A unified view of substorm sequences, J. Geophys. Res., 83, 21032108, 1978.

Kamide, Y., S.-I. AKasofu, and E. P. RigGer, Co-existence of two substorms in the midight sector, J. Geophys. Res., 82, 1620-1624, 1977.

Kamide, Y., P. D. Perreault, S.-I. Akasofu, and J. D. Winningham, Dependence probability on the interplanetary magnetic field and on the size of the auroral oval, J. Geophys. Res., 82, 5521-5528, 1977.

KAN, J. R., Non-linear tearing structures in equilibrium current sheet, Planet. Space Sci., 27, 351354, 1979.

KAN, J. R. and S.-I. AKasofu, A mechanism for current interruption in a collisionless plasma, J. Geophys. Res., 83, 735-738, 1978.

LUI, A. T. Y. and J. R. BURRows, On the location of auroral arcs near substorm onsets, J. Geophys. Res., 83, 3342-3348, 1978.

MCPherron, R. L., The use of ground magnetograms to time the onset of magnetospheric substorms, J. Geomag. Geoelectr., 30, 149-163, 1978.

Meng, C.-I., S.-I. AKasofu, and K. A. Anderson, Dawn-dusk gradient of the precipitation of low-energy electrons over the polar cap and its relation to the interplanetary magnetic field, J. Geophys. Res., 82, 5271-5275, 1977.

Mitchell, H. G., Jr. and J. R. KAN, Current interruption in a collisionless plasma by non-linear electrostatic waves, Planet. Space Sci., 27, 933-937, 1979.

Mizera, P. F. and J. F. Fennell, Satellite observations of polar, magnetotail lobe, and interplanetary electrons at low energies, Rev. Geophys. Space Phys., 16, 147-180, 1978.

NishidA, A., Substorm onset in the magnetotail, J. Geomag. Geoelectr., 30, 165-182, 1978.

NishidA, A. and C. T. Russell, On the expected signatures of reconnection in the magnetotail, J. Geophys. Res., 83, 3890-3892, 1978.

Prabhakaran Nayar, S. R. and P. Revathy, Anomalous resistivity in the geomagnetic tail region, Planet. Space Sci., 26, 1033-1035, 1978.

Pellinen, R. J., Model for the onset of a magnetospheric substorm, Planet. Space Sci., 27, 19-30, 1979.

Pellinen, R. J. and W. J. Heikkila, Energization of charged particles to high energies by an induced substorm electric field within the magnetotail, J. Geophys. Res., 83, 1544-1550, 1978.

Pellinen, R. J. and W. J. HeikkIlA, Observations of auroral fading before breakup, J. Geophys. Res., 83, 4207-4216, 1979.

Troshichev, O. A., N. P. DMitrieva, and B. M. KuZnetsov, Polar cap magnetic activity as a 
signature of substorm development, Planet. Space Sci., 27, 217-221, 1979.

c. Distant magnetosphere observations and their theories

Akasofu, S.-I., A. T. Y. Lui, C.-I. Meng, and M. Haurwitz, Need for a three dimensional analysis of magnetic fields in the magnetotail during substorms, Geophys. Res. Lett., 5, 283286, 1978.

BAKer, D. N. and E. C. Stone, Observations of energetic electrons ( $E \geq 200 \mathrm{keV})$ in the earth's magnetotail: plasma sheet and fireball observations, J. Geophys. Res., 82, 1532-1546, 1977.

BAKer, D. N. and E. C. Stone, The magnetopause electron layer along the distant magnetotail, Geophys. Res. Lett., 4, 133-136, 1977.

BIRN, J., Self-consistent magnetotail theory: General solution for the quiet tail with vanishing field-aligned currents, J. Geophys. Res., 84, 5143-5152, 1979.

CaAn, M. N., D. H. Fairfield, and E. W. Hones, Jr., Magnetic fields in flowing magnetotail plasmas and their significance for magnetic reconnection, J. Geophys. Res., 84, 1971-1976, 1979.

ChaO, J. K., J. R. Kan, A. T. Y. LuI, and S.-I. AKAsofu, A model for thinning of the plasma sheet, Planet. Space Sci., 25, 703-710, 1977.

Cahill, L. J., Jr., and T. L. Skillman, The magnetopause at $5.2 R_{E}$ in August 1972: Magnetopause motion, J. Geophys. Res., 82, 1566-1572, 1977.

Coroniti, F. V., F. L. Scarf, L. A. Frank, and R. P. Lepping, Microstructure of a magnetotail fireball, Geophys. Res. Lett., 4, 219-222, 1977.

Coroniti, F. V., L. A. Frank, R. P. Lepping, F. L. SCARf, and K. L. ACkerson, Plasma flow pulsations in earth's magnetic tail, J. Geophys. Res., 83, 2162-2168, 1978.

DeCoster, R. J. and L. A. Frank, Observations pertaining to the dynamics of the plasma sheet, J. Geophys. Res., 84, 5099-5121, 1979.

FAIRFIELD, D. H., On the average configuration of the geomagnetic tail, J. Geophys. Res., 84, 1950-1958, 1979.

Formisano, V., Properties of energetic electrons of magnetospheric origin in the magnetosheath and in the solar wind-correlation with geomagnetic activity, Planet. Space Sci., 27, 867-879, 1979.

Frank, L. A. and K. L. Ackerson, Several recent findings concerning the dynamics of the earth's magnetotail, Space Sci. Rev., 23, 375-392, 1979.

Freeman, J. W., H. K. Hills, T. W. Hill, P. H. ReifF, and D. H. Hardy, Heavy ion circulation in the earth's magnetosphere, Geophys. Res. Lett., 4, 195-197, 1977.

Galeev, A. A., F. V. Coroniti, and M. Ashour-Abdalla, Explosive tearing mode reconnection in the magnetotail, Geophys. Res. Lett., 5, 707-710, 1978.

HonEs, E. W., Jr., Substorm processes in the magnetotail: comments on 'On hot tenuous plasmas, fireballs, and boundary layers in the earth's magnetotail' by L. A. Frank, K. L. Ackerson, and R. P. Lepping, J. Geophys. Res., 82, 5633-5640, 1977.

Hones, E. W., Jr., Comment on 'On hot tenuous plasmas, fireballs, and boundary layers in the earth's magnetotail' by L. A. Frank, K. L. Ackerson, and R. P. Lepping, J. Geophys. Res., 83, 1183-1186, 1978.

Hones, E. W., Jr., Processes at the magnetotail boundary: Comments on 'On hot tenuous plasma, fireballs, and boundary layers in the earth's magnetotail' by L. A. Frank, K. L. Ackerson, and R. P. Lepping, J. Geophys. Res., 83, 2216-2227, 1978.

Hones, E. W., Jr., Transient phenomena in the magnetotail and their relation to substorms, Space Sci. Rev., 23, 393-410, 1979.

Hones, E. W., Jr., G. Paschmann, S. J. Bame, J. R. Asbridge, N. Sckopke, and K. Schindler, 
Vortices in magnetospheric plasma flow, Geophys. Res. Lett., 5, 1059-1062, 1978.

Intviligator, D. S., H. R. Collard, J. D. Mikalov, O. L. VaisherG, and J. H. Wolfe, Evidence for earth magnetospheric tail associated phenomena at 3,100 $R_{E}$, Geophys. Res. Lett., 6, 585588, 1979.

Kirsch, E., S. M. Krimigis, E. T. Sarris, R. P. Lepping, and T. P. Armstrong, Possible evidence for large, transient electric fields in the magnetotail from oppositely directed anisotropics of energetic protons and electrons, Geophys. Res. Lett., 4, 137-140, 1977.

Lin, R. P., K. A. Anderson, J. E. McCoy, and C. T. Russell, Observations of magnetic merging and the formation of the plasma sheet in the earth's magnetotail, J. Geophys. Res., 82, 27612773, 1977.

LuI, A. T. Y., Estimates of current changes in the geomagnetotail associated with a substorm, Geophys. Res. Lett., 5, 853-857, 1978.

Lui, A. T. Y., C.-I. Meng, and S.-I. Akasofu, Search for the magnetic neutral line in the nearearth plasma sheet, 3, an extensive study of magnetic field observations at the lunar distance, J. Geophys. Res., 82, 3603-3613, 1977.

LuI, A. T. Y., C.-I. Meng, and S.-I. AKAsofu, Search for the magnetic neutral line in the nearearth plasma sheet; 2, systematic study of IMP6 magnetic field observations, J. Geophys. Res., 82, 1547-1565, 1977.

Lui, A. T. Y., C.-I. Meng, and S.-I. Akasofu, Wavy nature of the magnetotail neutral sheet, Geophys. Res. Lett., 5, 279-281, 1978.

Lui, A. T. Y., L. A. Frank, K. L. Ackerson, C.-I. Meng, and S.-I. Akasofu, Systematic study of plasma flow during plasma sheet thinnings, J. Geophys. Res., 82, 4815-4825, 1977.

Lui, A. T. Y., L. A. Frank, K. L. Ackerson, C. -I. Meng, and S.-I. Akasofu, Plasma flows and magnetic field vectors in the plasma sheet during substorms, J. Geophys. Res., 83, 38493858, 1978.

Pytte, T., R. L. McPherron, E. W. Hones, Jr., and H. I. West, Jr., Multiple-satellite studies of magnetospheric substorms: Distinction between polar magnetic substorms and convectiondriven negative bays, J. Geophys. Res., 83, 663-679, 1978.

PytTe, T. and H. I. WeST, Jr., Ground-satellite correlations during presubstorm magnetic field configuration changes and plasma sheet thinning in the near-earth magnetotail, J. Geophys. Res., 83, 3791-3804, 1978.

SAITo, T., Long period irregular magnetic pulsation, Pi3, Space Sci. Rev., 21, 427-467, 1978.

Shirman, B. I., B. A. Undsenkov, and V. A. Shapiro, Determination of substorm onset from the geomagnetic D-perturbation data, J. Geomag. Geoelectr., 30, 187-189, 1978.

Southwood, D. J., The role of hot plasma in magnetospheric convection, J. Geophys. Res., 82, 5512-5520, 1977.

Troshichev, O. A., N. P. Dmitrieva, and B. M. Kuznetsov, Polar cap magnetic activity as a signature of substorm development, Planet. Space Sci., 27, 217-221, 1979.

Villante, U., An overview by Pioneer's observations of the distant geomagnetic tail, Space Sci. Rev., 20, 123-143, 1977.

Wagner, J. S., J. R. KAN, and S.-I. Akasofu, Particle dynamics in the plasma sheet, J. Geophys. Res., 84, 891-897, 1979.

West, H. I., Jr., R. M. BuCK, and M. G. Kivelson, On the configuration of the magnetotail near midnight during quiet and weakly disturbed periods: State of the magnetosphere, $J$. Geophys. Res., 83, 3805-3817, 1978.

West, H. I., Jr., R. M. BuCK, and M. G. Kivelson, On the configuration of the mangetotail near midnight during quiet and weakly disturbed periods: Magnetic field modeling, J. Geophys. Res., 83, 3819-3829, 1978. 
Yamamoto, T. and T. TAmao, Adiabatic plasma convection in the tail plasma sheet, Planet. Space Sci., 26, 1185-1191, 1978.

III. Plasma Injection

a. Ring current and plasmasphere

Baker, D. N., P. Stanning, E. W. Hones, Jr., P. R. Higbie, and R. D. Belian, Strong electron pitch angle diffusion observed at geostationary orbit, Geophys. Res. Lett., 6, 205-208, 1979.

Bavassano-Cattaneo, M. B. and V. Formisano, Low energy electrons and protons in the magnetosphere, Planet. Space Sci., 26, 51-58, 1978.

Bhatia, K. G. and G. S. Lakhina, Drift instabilities associated with the particles in ring current and inner edge of plasma sheet, Planet. Space Sci., 26, 985-992, 1978.

Chen, A. J. and J. M. Grebowsky, Dynamical interpretation of observed plasmasphere deformations, Planet. Space Sci., 26, 661-672, 1978.

Cowley, S. W. H., Pitch angle dependence of the charge-exchange lifetime of ring current ions, Planet. Space Sci., 25, 385-393, 1977.

Debrunner, H., E. Flückiger, H. von Mandach, and M. Arens, Determination of the ring current radii from cosmic ray neutron monitor data for the 17 December 1971 magnetic storm, Planet. Space Sci., 27, 577-581, 1979.

Erickson, K. W., R. L. Swanson, R. J. WAlker, and J. R. Winckler, A study of magnetosphere dynamics during auroral electrojet events by observations of energetic electron intensity changes at synchronous orbit, J. Geophys. Res., 84, 931-942, 1979.

Ghielmetti, A. G., R. G. Johnson, R. D. Sharp, and E. G. Shelley, The latitudinal, diurnal and altitude distributions of upward flowing energetic ions of ionospheric origin, Geophys. Res. Lett., 5, 59-62, 1978.

Gringanz, K. I. and V. V. Bzrukikh, Plasmasphere of the earth (review), Geomagn. Aeron., 17, 523-533, 1977.

Gurgiolo, C., C. S. Liu, B. Mank, G. K. Park, and C. McIlwain, Plasma injéction and diamagnetism, J. Geophys. Res., 84, 2049-2056, 1979.

Johnson, R. G., R. D. Sharp, and E. G. Shelley, Observations of ions of ionospheric origin in the storm-time ring current, Geophys. Res. Lett., 4, 403-406, 1977.

Kaye, S. M. and M. G. Kivelson, Time dependent convection electric fields and plasma injection, J. Geophys. Res., 84, 4183-4188, 1979.

Kudela, K., B. Dobrovolska, A. V. Zakharov, and V. A. Kuznetsova, $440 \mathrm{keV}$ proton precipitation at middle latitudes during the recovery phase of magnetic storms, Planet. Space Sci., 25, 1186-1190, 1977.

Kuznetsov, S. N., L. L. Lazutin, and V. Ye. Tsivs, Dynamics of trapped electrons in the auroral zone during a substorm, Geomagn. Aeron., 17, 180-182, 1977.

LyONS, L. R., An alternative analysis of low- and high-altitude observations of ring current ions during a storm recovery phase, J. Geophys. Res., 82, 2367-2370, 1977.

Lyons, L. R., Adiabatic evolution of trapped particle pitch angle distributions during a storm main phase, J. Geophys. Res., 82, 2428-2432, 1977.

Lyons, L. R. and A. D. RICHMOND, Low-latitude $E$ region ionization by energetic ring current particles, J. Geophys. Res., 83, 2201-2204, 1978.

Miller, N. J. and J. M. Gvebowsky, Simultaneous in situ magnetospheric and ionospheric detection of detached plasmas, Geophys. Res. Lett., 4, 369-372, 1977.

Parks, G. K., C. S. Lin, B. Mauk, S. DeForest, and C. E. McIlwain, Characteristics of magnetospheric particle injection deduced from events observed on August 18, 1974, J. Geophys. Res., 82, 5208-5214, 1977. 
PrangÉ, R., Energetic (keV) ions of ionospheric origin in the magnetosphere; A review, Ann. Geophys., 34, 187-230, 1978.

RaO, L. D. V., W. J. BuRKe, M. Kanal, and R. C. Sagalyn, Injun 5 low-energy plasma observations during a major magnetic storm, J. Geophys. Res., 83, 3217-3225, 1978.

Sharp, R. D., E. G. Shelley, and R. G. Johnson, A search for helium ions in the recovery phase of a magnetic storm, J. Geophys. Res., 82, 2361-2366, 1977.

Shelley, E. G., Heavy ions in the magnetosphere, Space Sci. Rev., 23, 465-497, 1979.

SisCOE, G. L., A quasi-self-consistent axially symmetric model for the growth of a ring current through earthward motion from a pre-storm configuration, Planet. Space Sci., 27, 285-295, 1979.

Siscoe, G. L., A Dst contribution to the equatorward shift of the aurora, Planet. Space Sci., 27, 997-1000, 1979.

WeBB, D. C. and L. J. LANZerotTI, Temporal variations in slant total plasmasphere content and their relationship to the ring current intensity and the plasmapause, J. Geophys. Res., 82, 5201-5207, 1977.

Yemel'Yanenko, S. N., S. N. KuzNetsov, and V. G. Stolpovkiy, Outer radiation belt during a strong magnetic storm, Geomagn. Aeron., 18, 141-144, 1978.

IV. Aurora

a. Morphology

BerkeY, F. T., Observations of pulsating aurora in the day sector auroral zone, Planet. Space Sci., 26, 635-650, 1978.

Cazeneuve, H. A. and G. E. Guerrero, Harmonic analysis of auroral pulsations, Ann. Geophys., 34, 97-106, 1978.

DandeKaR, B. S. and C. P. PiKe, The midday, discrete auroral gap, J. Geophys. Res., 83, 42274236, 1978.

Davis, T. N., Observed characteristics of auroral forms, Space Sci. Rev., 22, 77-106, 1978.

EATHER, R. H., DMSP calibration, J. Geophys. Res., 84, 4134-4144, 1979.

Ismait, S., D. D. Wallis, and L. L. CogGer, Characteristics of polar cap sun-aligned arcs, $J$. Geophys. Res., 82, 4741-4749, 1977.

KAWASAKI, K. and G. ROSTOKER, Auroral motion and magnetic variations associated with the onset of auroral substorm, J. Geophys. Res., 84, 7113-7122, 1979.

Luhmann, J. G., Auroral pulsations from atmospheric waves, J. Geophys. Res., 84, 4224-4228, 1979.

MenG, C.-I., Diurnal variation of the auroral oval size, J. Geophys. Res., 84, 5319-5324, 1979.

Meng, C.-I., R. H. Holzworth, and S.-I. AKasofu, Auroral circle-delineating the poleward boundary of the quiet auroral belt, J. Geophys. Res., 82, 164-172, 1977.

Moshupi, M. C., L. L. Cogger, D. D. Waluis, J. S. Murphree, and C. D. Anger, Auroral patches in the vicinity of the plasmapause, Geophys. Res. Lett., 4, 37-40, 1977.

Moshupi, M. C., C. D. Anger, J. S. Murphree, D. D. Wallis, J. H. WhitTeKer, and L. H. BRACE, Characteristics of trough region auroral patches and detached arcs observed by ISIS 2, J. Geophys. Res., 84, 1333-1346, 1979.

PIKE, C. P. and B. S. DANDEKAR, Evening sector auroral oval dynamics from DMSP photographs, J. Geophys. Res., 84, 3389-3402, 1979.

Pike, C. P., J. A. Whalen, and J. Buchau, A 12-hour case study of auroral phenomena in the midnight sector: $F$ layer and 6,300 $\AA$ measurements, J. Geophys. Res., 82, 3547-3556, 1977.

RoYRviK, O. and T. N. DAvis, Pulsating aurora: Local and global morphology, J. Geophys. Res., 82, 4720-4740, 1977. 
SharP, W. E., The ultraviolet aurora: The spectrum between 2,100 $\AA$ and 2,300 $\AA$, Geophys. Res. Lett., 5, 703-705, 1978.

SisCoE, G. L., A Dst contribution to the equatorward shift of the aurora, Planet. Space Sci., 27, 997-1000, 1979.

Stenbaek-Nielsen, H. C. and T. J. Hallinan, Pulsating auroras: Evidence for noncollisional thermalization of procipitating electrons, J. Geophys. Res., 84, 3257-3271, 1979.

ThomAs, I. L. and F. R. Bond, A spherical harmonic analysis of the austral auroral oval, Planet. Space Sci., 26, 691-695, 1978.

Troitskaya, V. A. and O.V. Bolshakova, Dirunal latitude variation of the location of the dayside cusp, Planet. Space Sci., 25, 1167-1169, 1977.

Wallis, D. D., J. R. Burrows, M. C. Moshupi, C. D. Anger, and J. S. Murphree, Observations of particles precipitating into detached arcs and patches equatorward of the auroral oval, J. Geophys. Res., 84, 1347-1360, 1979.

Whalen, J. A., R. A. WAGNer, and J. Buchau, A 12-hour case study of auroral phenomena in the midnight sector: Oval, polar cap, and continuous auroras, J. Geophys. Res., 82, 3529-3546, 1977.

b. Field-aligned currents, ionospheric electric fields and currents, and magnetic disturbances

AgGSON, T. L. and J. P. HepPNER, Observations of large transient magnetospheric electric fields, J. Geophys. Res., 82, 5155-5164, 1977.

Anger, C. D., M. C. Moshupi, D. D. Wallis, J. S. Murphree, L. H. Brace, and G. G. Shepherd, Detached auroral arcs in the trough region, J. Geophys. Res., 83, 2683-2689, 1978.

Atrinson, G., Field-line merging and slipping, Geophys. Res. Lett., 5, 465-468, 1978.

AtKinson, G., Energy flow and closure of current systems in the magnetosphere, J. Geophys. Res., 83, 1089-1103, 1978.

Atrinson, G. and D. Hutchison, Effect of the day night ionospheric conductivity gradient on polar cap convective flow, J. Geophys. Res., 83, 725-729, 1978.

Banks, P. M. and F. Yasuhara, Electric fields and conductivity in the nighttime $E$-region: A new magnetosphere-ionosphere-atmosphere coupling effect, Geophys. Res. Lett., 5, 1047-1050, 1978.

BANNISTER, J. R. and D. I. Gough, Development of a polar magnetic substorm: A two dimensional magnetometer array study, Geophys. J. R. Astr. Soc., 51, 75-90, 1977.

BANNister, J. R. and D. I. Gough, A study of two polar magnetic substorms with a twodimensional magnetometer array, Geophys. J. RAS, 53, 1-26, 1978.

BARBosA, D. D., High-latitude field-aligned current sources and induced electric fields, J. Geophys. Res., 84, 5175-5180, 1979.

BaumjohanN, W., R. A. Greenwald, and F. Küppers, Joint magnetometer array and radar backscatter observations of auroral currents in Northern Scandinavia, J. Geophys., 44, 373383, 1978.

Baumjohann, W., J. Untiedt, and R. A. Greenwald, Joint two-dimensional observations of ground magnetic and ionospheric electric fields associated with auroral zone currents, $J$. Geophys. Res., 85, 1963-1978, 1980.

Blanc, M., P. Amayenc, P. Bauer, and C. Taieb, Electric field induced drifts from the French incoherent scatter facility, J. Geophys. Res., 82, 87-97, 1977.

BREKKE, A., The relationship between the Harang discontinuity and the substorm injection boundary, Planet. Space Sci., 25, 1119-1129, 1977.

BREKKE, A. and C. L. RiNo, High-resolution altitude profiles of the auroral zone energy dissipation due to ionospheric currents, J. Geophys. Res., 83, 2517-2524, 1978.

Brown, G. M. and R. WYNNE, Magnetic disturbance effects in the $E$ region of the ionosphere, 
Planet. Space Sci., 25, 651-656, 1977.

CASSERly, R. T., Jr., Observation of a structured auroral field-aligned current system, J. Geophys. Res., 82, 155-163, 1977.

Campbell, W. H., Occurrence of $A E$ and Dst geomagnetic index levels and the selection of the quietest days in a year, J. Geophys. Res., 84, 875-881, 1979.

CHIU, Y. T. and M. Schulz, Self-consistent particle and parallel electrostatic field distributions in the magnetospheric-ionospheric auroral region, J. Geophys. Res., 83, 629-642, 1978.

DAMASKe, D., Magnetospheric modulation of geomagnetic activity, I. Harmonic analysis of quasilogarithmic indices Km, Kn and Ks, Ann. Geophys., 33, 461-478, 1977.

D'Angelo, N., A simplified model of polar cap electric fields, Ann. Geophys., 33, 341-346, 1977.

DE LA BeAujardiere, O., R. VondraK, and M. BARON, Radar observations of electric fields and currents associated with auroral arcs, J. Geophys. Res., 82, 5051-5062, 1977.

Denisenko, V. V. and V. G. Pivovarov, Computation of current systems in the polar ionosphere, Geomagn. Aeron., 17, 28-31, 1977.

FAIRFIELD, D. H., Electric and magnetic fields in the high-latitude magnetosphere, Rev. Geophys. Space Phys., 15, 285-298, 1977.

Fälthammar, C.-G., Problems related to macroscopic electric fields in the magnetosphere, Rev. Geophys. Space Phys., 15, 457-466, 1977.

Gizler, V. A., V. S. Semenov, and O. A. Troshichev, Electric fields and currents in the ionosphere generated by field-aligned currents observed by TRIAD, Planet. Space Sci., 27, 223-231, 1979.

Goldstein, H. and K. Schindler, On the role of the ionosphere in substorms: Generation of field-aligned currents, J. Geophys. Res., 83, 2574-2578, 1978.

Gupta, J. C. and E. I. LOOMER, Influence of $A E$ index of substorms appearing north of Cambridge Bay, Planet. Space Sci., 27, 1019-1025, 1979.

Holzworth, R. H., J.-J. Berthelier, D. K., Cullers, U. V. Fahleson, C.-G. Fälthammar, M. K. Hudson, L. Jaolnen, M. C. Kelley, P. J. Kellog, P. Tanskanen, M. Temerin, and F. S. MOZER, The large-scale ionospheric electric field: Its variation with magnetic activity and relation to terrestrial kilometric radiation, J. Geophys. Res., 82, 2735-2742, 1977.

HoRwitz, J. L., J. R. DoupNIK, and P. M. BAKs, Chatanika radar observations of the latitudinal distributions of auroral zone electric fields, conductivities and currents, J. Geophys. Res., 83, 1463-1481, 1978.

Horwitz, J. L., J. R. Doupnik, P. M. BAnks, Y. KAmide, and S.-I. AkAsofu, The latitudinal distributions of auroral zone electric fields and ground magnetic perturbations and their response to variations in the interplanetary magnetic field, J. Geophys. Res., 83, 2071-2084, 1978.

Hughes, T. J. and G. Rostoker, Current flow in the magnetosphere and ionosphere during periods of moderate activity, J. Geophys. Res., 82, 2271-2282, 1977.

Hughes, T. J. and G. Rostoker, A comprehensive model current system for high-latitude magnetic activity, I. The steady state system, Geophys. J. RAS., 58, 525-569, 1979.

Irjma, T. and T. A. Potemra, Large-scale characteristics of field-aligned currents associated with substorms, J. Geophys. Res., 83, 599-615, 1978.

IsAYEV, N. V. and N. K. OsIPOV, Auroral electrons and the conductivity of the high-latitude ionosphere, Geomagn. Aeron., 17, 571-574, 1977.

JALONEN, L. and T. NYGRÉN, On the discrepancy between the magnetic $D$-component and the overhead horizontal current at high-latitudes, Planet. Space Sci., 27, 1027-1032, 1979.

Johnson, F. S., The driving force for magnetospheric convection, Rev. Geophys. Space Phys., 16, 161-167, 1978.

KAmide, Y., On current continuity at the Harang discontinuity, Planet. Space Sci., 26, 237-244, 1978. 
KAMIDE, Y. and A. BReKKe, Altitude of the eastward and westward auroral electrojets, J. Geophys. Res., 82, 2851-2853, 1977.

KAMIDE, Y. and J. L. HoRwITz, Chatanika radar observations of ionospheric and field-aligned currents, J. Geophys. Res., 83, 1063-1070, 1978.

Kamide, Y. and S. Matsushita, Simulation studies of ionospheric electric fields and currents in relation to field-aligned currents, 2. Substorms, J. Geophys. Res., 84, 4099-4115, 1979.

KAmide, Y. and S. Matsushita, Simulation studies of ionospheric electric fields and currents in relation to field-aligned currents, 1. Quiet periods, J. Geophys. Res., 84, 4083-4098, 1979.

KAMIDE, Y. and G. Rostoker, The spatial relationship of field-aligned currents and auroral electrojets to the distribution of nightside auroras, J. Geophys. Res., 82, 5589-5608, 1977.

Kamide, Y. and J. D. Winningham, A statistical study of the 'instantaneous' nightside auroral oval: The equatorward boundary of electron precipitation as observed by the Isis 1 and 2 satellites, J. Geophys. Res., 82, 5573-5588, 1977.

Kamide, Y., J. S. Murphree, C. D. Anger, F. T. Berkey, and T. A. Potemra, Nearly simultaneous observations of field-aligned currents and visible auroras by the Triad and Isis 2 satellites, J. Geophys. Res., 84, 4425-4431, 1979.

KaWASAKI, K. and G. Rostoker, Perturbation magnetic fields and current systems associated with eastward drifting auroral structures, J. Geophys. Res., 84, 1464-1480, 1979.

KIrSCH, E., M. Scholer, and L. RossBerg, Substorm related electron and proton bursts over the polar caps, Planet. Space Sci., 25, 931-939, 1977.

KisAbeth, J. L. and G. Rostoker, Modeling of three-dimensional current systems associated with magnetospheric substorms, Geophys. J. RAS., 49, 655-683, 1977.

KISABETH, J. L. and G. RostoKeR, Relationship of noise in the frequency range $100<f<500 \mathrm{kHz}$ to auroral arcs and field-aligned current and implications regarding acceleration of auroral electrons, J. Geophys. Res., 84, 853-868, 1979.

Kuznetsov, B. M. and O. A. Troshichev, On the nature of polar cap magnetic activity during undisturbed periods, Planet. Space Sci., 25, 15-21, 1977.

Labachevskiy, L. A., N. P. Sergeyeniko, O. S. Sergeyenko, and L. A. Yudovich, Effects of electric fields during magnetospheric substorms, according to Doppler sounding, Geomagn. Aeron., 18, 287-289, 1978.

Mahon, H. P., M. Smiddy, and R. C. SAGAlyn, Electric fields in diffuse aurora, Planet. Space Sci., 25, 859-868, 1977.

Mallinckodt, A. J. and C. W. CARLSON, Relations between transverse electric fields and fieldaligned currents, J. Geophys. Res., 83, 1426-1432, 1978.

Marubashi, K., Effects of convection electric field on the thermal plasma flow between the ionosphere and the protonosphere, Planet. Space Sci., 27, 603-615, 1979.

Mayaud, P. N., The annual and daily variations of the Dst index, Geophys. J. RAS., 55, 193-201, 1978.

MAYAUD, P. N., Morphology of the transient irregular variations of the terrestrial magnetic fields, and their main statistical laws, Ann. Geophys., 34, 243-250, 1978.

Maynard, N. C., D. S. Evans, B. Maehlum, and A. Egeland, Auroral vector electric field and particle comparisons 1. Premidnight convection topology, J. Geophys. Res., 82, 2227-2234, 1977.

MCDiarmid, I. B., J. R. BARrows, and M. D. Wilson, Large-scale magnetic field perturbations and particle measurements at 1,400 km on the dayside, J. Geophys. Res., 84, 1431-1441, 1979.

McDiarmid, I. B., E. E. Budzinski, M. D. Wilson, and J. R. Barrow, Reverse polarity fieldaligend current at high latitudes, J. Geophys. Res., 82, 1513-1518, 1977.

Mishin, V. M., High-latitude geomagnetic variations and substorms, Space Sci. Rev., 20, 621-693, 1977. 
Mizera, P. F. and J. F. Fennell, Signatures of electric fields from high and low altitude particle distributions, Geophys. Res. Lett., 4, 311-314, 1977.

Morgan, B. G. and R. L. ARNoldy, A determination of $F$ region convective electric fields from rocket measurements of ionospheric thermal ion spectra, J. Geophys. Res., 83, 1055-1061, 1978.

Nielsen, E. and R. A. Greenwald, Electron flow and visual aurora at the Harang discontinuity, J. Geophys. Res., 84, 4189-4200, 1979.

Nisbet, J. S., M. J. Miller, and L. A. CARPenter, Currents and electric fields in the ionosphere due to field aligned auroral currents, J. Geophys. Res., 83, 2647-2657, 1978.

Nopper, R. W., Jr. and R. C. CARovillano, Polar-equatorial coupling during magnetically active periods, Geophys. Res. Lett., 5, 699-702, 1978.

OldENBURG, D. W., A quantitative technique for modeling ionospheric and magnetospheric current distributions, J. Geophys. Res., 83, 3320-3326, 1978.

OsIPov, N. K. and A. M. MzHAYEv, Dynamics and interrelation between the structures of magnetospheric convection and of the polar ionosphere, Geomagn. Aeron., 18, 321-325, 1978.

Petelski, E. F., U. Fahleson, and S. D. Shawhan, Models for quasi-periodic electric fields and associated electron precipitation in the auroral zone, J. Geophys. Res., 83, 2489-2498, 1978.

Ponyavin, D. I., M. I. Pudovkin, and S. S. Sazhin, Self-consistent field-aligned electric field in the earth's magnetosphere, Geomagn. Aeron., 17, 323-325, 1977.

Pudovkin, M. I. and V. S. Semenov, Peculiarities of the MHD-Flow by the magnetopause and generation of the electric field in the magnetosphere, Ann. Geophys., 34, 423-435, 1978.

ReifF, R. H., J. L. BuRch, and R. A. HeElis, Dayside auroral arcs and convection, Geophys. Res. Lett., 5, 391-394, 1978.

Rostoker, G. and T. J. Hughes, A comprehensive model current system from high-latitude magnetic activity, II. The substorm component, Geophys. J. RAS., 58, 571-581, 1979.

Rostoker, G., J. D. Winningham, K. Kawasaki, J. R. Burrows, and T. J. Hughes, Energetic particle precipitation into the high-latitude ionosphere and the auroral electrojets, 2. Eastward electrojet and field-aligned current flow at the dusk meridian, J. Geophys. Res., 84, 2006-2018, 1979.

Saflekos, N. A., T. A. Potemra, and T. Inima, Small-scale transverse magnetic disturbances in the polar regions observed by Triad, J. Geophys. Res., 83, 1493-1502, 1978.

Sato, T., Auroral and equatorial two-stream irregularities: Difference in nonlinear state, $J$. Geophys. Res., 82, 5195-5200, 1977.

Senatorov, V. N., O. I. Shumikov, and G. V. Popov, Numerical simulation of magnetospheric plasma convection, Geomagn. Aeron., 18, 201-204, 1978.

Shawhan, S. D., C.-G. Fälthammar, and L.P. Block, On the nature of large auroral zone electric fields at $1-R_{E}$ altitude, J. Geophys. Res., 83, 1049-1054, 1978.

StERN, D. P., Large-scale electric fields in the earth's magnetosphere, Rev. Geophys. Space Phys., 15, 156-194, 1977.

St.-MAURICE, J.-P. and R. W. SchunK, Auroral ion velocity distributions for a polarization collision model, Planet. Space Sci., 25, 243-260, 1977.

Untiedt, J., R. Pellinen, F. Küppers, H. J. Opgenoorth, W. D. Pelster, W. Baumjohann, H. Ranta, J. Kangas, P. Czechowsky, and W. J. Heikkila, Observations of the initial development of an auroral and magnetic substorm at magnetic midnight, J. Geophys., 45, 41-65, 1978.

Volland, H., A model of the magnetospheric electric convection field, J. Geophys. Res., 83, 26952699, 1978.

Wedde, T., J. R. Doupnik, and P. M. Banks, Chatanika observations of the latitudinal structure 
of electric fields and particle precipitation on November 21, 1975, J. Geophys. Res., 82, 27432751, 1977.

Winningham, J. D., K. KaWASAKI, and G. Rostoker, Energetic particle precipitation into the high-latitude ionosphere and the auroral electrojets, 1. Definition of electrojet boundaries using energetic electron spectra and ground-based magnetometer data, J. Geophys. Res., 84, 1993-2005, 1979.

ZAKHAROV, V. YE. and M. A. Nikitin, Simulation of electric fields of magnetospheric origin in the inosphere, V, Geomagn. Aeron., 18, 332-336, 1978.

Zakharov, V. YE. and L. A. Yudovich, Simulation of electric field of magnetospheric origin in the ionosphere, I, Geomagn. Aeron., 18, 173-176, 1978.

c. Accleration processes, precipitation, arc formation

AlfVÉN, H., Electric currents in cosmic plasmas, Rev. Geophys. Space Phys., 15, 271-284, 1977.

Ashour-Abdalla, M. and R. M. Throne, The importance of electrostatic ion-cyclotron instability for quiet-time proton auroral precipitation, Geophys. Res. Lett., 4, 45-48, 1977.

Bassolo, V.S. and N. K. OsIPov, Electrodynamic processes in the region of injection of auroral particles, Geomagn. Aeron., 17, 68-70, 1977.

Boswell, R. W., Energetic ions and electromagnetic radiations in auroral regions, Geophys. Res. Lett., 5, 395-398, 1978.

BRyant, D. A., D. S. HALl, and D. R. LePINe, Electron acceleration in an array of auroral arcs, Planet. Space Sci., 26, 81-92, 1978.

Evans, D. S., N. C. Maynard, J. Trøim, T. Jacobsen, and A. Egeland, Auroral vector electric field and particle comparisons, 2, electrodynamics of an arc, J. Geophys. Res., 82, 2235-2249, 1977.

Foster, J. C. and J. R. Burrows, Electron fluxes over the polar cap, 2, electron trapping and energization on open field lines, J. Geophys. Res., 82, 5155-5170, 1977.

Goertz, C. K., Double layers and electrostatic shocks in space, Rev. Geophys. Space Phys., 17, 418426, 1979.

Hallinan, T. J., N. C. Stenbaek-Nielsen, and J. R. WinckleR, The Echo 4 electron beam experiment: Television observation of artifical auroral streaks indicating strong beam interactions in the high-latitude magnetosphere, J. Geophys. Res., 83, 3263-3272, 1978.

Hubbard, R. F. and G. Joyce, Simulation of auroral double layers, J. Geophys. Res., 84, 42974304, 1979.

Hudson, M. K. and F. S. Mozer, Electrostatic shocks, double layers and anomalous resistivity in the magnetosphere, Geophys. Res. Lett., 5, 131-134, 1978.

Hudson, M. K., R. L. Lysakarl, and F. S. Mozer, Magnetic field-aligned potential drops due to electrostatic ion cyclotron turbulence, Geophys. Res. Lett., 5, 143-146, 1978.

HultQvist, B., The hot ions component of the magnetospheric plasma and some relations to the electron component-observations and physical implications, Space Sci. Rev., 23, 581-675, 1979.

HultQvist, B. and H. Borg, Observations of energetic ions in inverted $V$ events, Planet. Space Sci., 26, 673-689, 1978.

ImHoF, W. L., G. H. NAKANO, and J. B. ReAGAN, Satellite observations of impulsive Bremsstrahlund $\mathrm{X}$ ray events associated with substorms, J. Geophys. Res., 83, 4237-4243, 1978.

Johnstone, A. D., Precipitation of charged particles by a parallel electric field, Planet. Space Sci., 26, 581-594, 1978.

Kan, J. R., L. C. LeE, and S.-I. Akasofu, Two-dimensional potential double layers and discrete auroras, J. Geophys. Res., 84, 4305-4315, 1979.

Kaufmann, R. L., P. B. Dusenberg, B. J. Thomas, and R. L. Arnoldy, Auroral electron distribu- 
tion function, J. Geophys. Res., 83, 586-598, 1978.

Kelley, M. C. and C. W. CARlson, Observations of intense velocity shear and associated electrostatic waves near an auroral arc, J. Geophys. Res., 82, 2343-2348, 1978.

Kintner, P. M. and L. J. CAhill, Jr., Electric field oscillations measured near an auroral arc, Planet. Space Sci., 26, 555-558, 1978.

Kintner, P. M., M. C. Kelley, and F. S. Mozer, Electrostatic hydrogen cyclotron waves near one earth radius altitude in the polar magnetosphere, Geophys. Res. Lett., 5, 139-142, 1978.

KIrSCH, E., M. Scholer, and L. Rossberg, Substorm related electron and proton bursts over the polar caps, Planet. Space Sci., 25, 931-939, 1977.

Klumpar, D. M., Transversely accelerated ions: An ionospheric source of hot magnetospheric ions, J. Geophys. Res., 84, 4229-4237, 1979.

LenNARTsSon, W., On high-latitude convection field inhomogeneities, parallel electric fields and inverted-V precipitation events, Planet. Space Sci., 25, 89-101, 1977.

Lui, A. T. Y., D. Venkatesan, C. D. Anger, S.-I. Akasofu, W. J. Heikkila, J. D. Winningham, and J. R. BARRows, Simultaneous observations of particle precipitations and auroral emissions by the ISIS 2 satellite in the 19-24 MLT sector, J. Geophys. Res., 82, 2210-2226, 1977.

Lyatskaya, A. M., V. B. Lyatskiy, and YU. P. MAL'TSER, Effect of field-aligned currents on the electron density profile, Geomagn. Aeron., 18, 155-158, 1978.

MAgGs, J. E., Electrostatic noise generated by the auroral electron beam, J. Geophys. Res., 83, 3173-3188, 1978.

Maltsev, Yu. P., W. B. Lyatsky, and A. M. Lyatskaya, Currents over the auroral arc, Planet. Space Sci., 25, 53-57, 1977.

McEwen, D. J., Electron precipitation observations from a rocket flight through the dayside auroral oval, Planet. Space Sci., 25, 1161-1175, 1977.

MENG, C.-I., Electron precipitations and polar auroras, Space Sci. Rev., 22, 223-300, 1978.

Meng, C.-I. and H. W. KROEHL, Intense uniform precipitation of low-energy electrons over the polar cap, J. Geophys. Res., 82, 2305-2313, 1977.

Meng, C.-I., B. MAuK, and C. E. MCIlwain, Electron precipitation of evening diffuse aurora and its conjugate electron fluxes near the magnetosphere equator, J. Geophys. Res., 84, 2545-2558, 1979.

Meng, C.-I., A. L. SNyder, Jr., and H. W. Kroehl, Observations of auroral westward traveling surges and electron precipitations, J. Geophys. Res., 83, 575-585, 1978.

Miura, A. and T. SATo, Shear instability: Auroral arc deformation and anomalous momentum transport, J. Geophys. Res., 83, 2109-2117, 1978.

Mozer, F. S., R. B. Torbert, U. V. Fahlesov, C.-G. Fälthammar, A. Goufalone, A. Pedersen, and C. T. Russell, Direct observations of a tangential electric field component at the magnetopause, Geophys. Res. Lett., 6, 305-308, 1979.

O'Neil, R. R., F. Bien, D. Burt, J. A. SANDock, and A. T. Stair, Jr., Summarized results of the artificial auroral experiment, precede, J. Geophys. Res., 83, 3273-3280, 1978.

O'Neil, R. R., O. Shepherd, W. P. Reidy, J. W. Carpenter, T. N. Davis, D. Newell, J. C. Ulwick, and A. T. StaIR, Jr., Excede 2 test, an artificial auroral experiment: Ground-based optical measurements, J. Geophys. Res., 83, 3281-3288, 1978.

Ossakow, S. L. and P. K. Chaturvedi, Current convective instability in the diffuse aurora, Geophys. Res., Lett., 6, 332-335, 1979.

Papadopoulus, K., A review of anomalous resistivity for the ionosphere, Rev. Geophys. Space Phys., 15, 113-127, 1977.

PARKs, G. K., C. Gurgido, and R. WeSt, Relativistic electron precipitation, Geophys. Res. Lett., 6, 393-396, 1979. 
Peterson, W. K., J. P. Doering, T. A. Potemra, C. O. Boström, and L. H. Brace, Measurements of magnetic field-aligned potential differences using high resolution conjugate photo electron energy spectra, Geophys. Res. Lett., 4, 373-376, 1977.

Peterson, W. K., J. P. Doering, T. A. Potemra, R. W. McEntire, C. O. Boström, R. A. HofFMAN, R. W. JANETZKE, and J. L. BURCH, Observation of $10-\mathrm{eV}$ to $25-\mathrm{keV}$ electrons in steady diffuse aurora from Atmosphere Explorer C and D, J. Geophys. Res., 82, 42-47, 1977.

RAITT, W. J. and J. J. SoJKA, Field-aligned suprathermal electron fluxes below $270 \mathrm{~km}$ in the auroral zone, Planet. Space Sci., 25, 5-13, 1977.

RaItT, W. J., R. W. Schunk, and P. M. Banks, The influence of covection electric fields on thermal proton outflow from the ionosphere, Planet. Space Sci., 25, 291-301, 1977.

Rees, M. H., A. I. Stewart, W. E. Sharp, P. B. Hays, R. A. Hoffman, L. H. Brace, J. P. Doering, and W. K. Peterson, Coordinated rocket and satellite measurements of an auroral event, 1. Satellite observations and analysis, J. Geophys. Res., 82, 2250-2258, 1977.

Rossberg, L., E. KIRSCH, and M. SCHOlER, Intense electron and proton fluxes poleward of the trapping boundary during a substorm expansion, J. Geophys. Res.,, 82, 2854-2858, 1977.

Sato, T., A theory of quiet auroral arcs, J. Geophys. Res., 83, 1042-1048, 1978.

Sharp, W. E. and M. H. ReEs, Coordinated rocket and satellite measurements of an auroral event, 2, the rocket observations and analysis, J. Geophys. Res., 84, 1977-1985, 1979.

SwIFT, D. W., Mechanisms for the discrete aurora-a review, Space Sci. Rev., 22, 35-75, 1978.

Torbert, R. B. and F.S. Mozer, Electrostatic shocks as the source of discrete auroral arcs, Geophys. Res. Lett., 5, 135-138, 1978.

Venkatarangan, P. and D. J. McEwen, Electron measurements (18 keV-20 eV) in auroral events, Planet. Space Sci., 27, 669-677, 1979.

Walt, M., L. L. Nevkivle, and W. E. Francis, Bremsstrahlung produced by precipitating electrons, J. Geophys. Res., 84, 967-973, 1979.

Weber, E. J., J. A. Whalen, R. A. Wagner, and J. Buchau, A 12-hour case study of auroral phenomena in the midnight sector: Electrojet and precipitating particle characteristics, $J$. Geophys. Res., 82, 3557-3572, 1977.

Wescott, E. M., H. C. Stenbaek-Nielsen, T. N. Davis, R. A. Jeffries, and W. H. Roach, The Tordo 1 polar cusp barium plasma injection experiment, J. Geophys. Res., 83, 1565-1575, 1978.

Whalen, B. A. and P. W. Daly, Do field-aligned auroral particle distributions imply acceleration by quasi-static parallel electric fields?, J. Geophys. Res., 84, 4175-4182, 1979.

\section{d. Kilometric radiations}

Benson, R. F. and W. CALVERT, ISIS 1 observations at the source of auroral kilometric radiation, Geophys. Res. Lett., 6, 479-482, 1979.

Feygin, F. Z., A. L. Kalisher, V. A. Pilipenko, O. A. Pokhotelov, and K. Dobés, On the theory of the generation of auroral radiation, Planet. Space Sci., 27, 913-923, 1979.

Green, J. L., D. A. Gurnett, and S. D. Shawhan, The angular distribution of auroral kilometric radiation, J. Geophys. Res., 82, 1825-1838, 1977.

Green, J. L., D. A. Gurnett, and R. A. Hoffman, A correlation between auroral kilometric radiation and inverted $V$ electron precipitation, J. Geophys. Res., 84, 5216-5222, 1979.

Kaiser, M. L. and J. K. AleXANDER, Terrestrial kilometric radiations, 3, average spectral properties, J. Geophys. Res., 82, 3273-3280, 1977.

Kellogg, P. J. and S. J. Monson, Radio emissions from the aurora, Geophys. Res. Lett., 6, 297 $300,1979$.

KAISER, M. L. and J. K. AleXander, Relationship between auroral substorms and the occurrence of terrestrial kilometric radiation, J. Geophys. Res., 82, 5283-5286, 1977. 
KaISer, M. L. and J. K. AleXANDeR, Relationship between auroral substorms and the occurrence of terrestrial kilometric radiation, J. Geophys. Res., 82, 5283-5286, 1977.

Roux, A. and R. Pellat, Coherent generation of the auroral kilometric radiation by nonlinear bearings between electrostatic waves, J. Geophys. Res., 84, 5189-5198, 1979.

Voots, G. R., D. A. GURNETT, and S.-I. AKASOFU, Auroral kilometric radiation as an indicator of auroral magnetic disturbances, J. Geophys. Res., 82, 2259-2266, 1977.

e. Radar aurora, absorption

Armstrong, R. J., F. T. Berkey, and T. Melebeye, The day to night absorption ratio in auroral zone riometer measurements, Planet. Space Sci., 25, 1193-1198, 1977.

Brown, R. R., Sudden commencement absorption events at the edge of the polar cap, J. Geophys. Res., 82, 2433-2435, 1977.

BRown, R. R., On the poleward expansion of ionospheric absorption regions triggered by sudden commencements of geomagnetic storms, $J$. Geophys. Res., 83, 1169-1171, 1978.

Cahill, L. J., Jr., R. A. Greenwald, and E. Nielsen, Auroral radar and rocket double-probe observations of the electric field across the Harang discontinuity, Geophys. Res. Lett., 5, 683686, 1978.

Haldoupis, C. and G. SofKo, VHF double-peaked spectra at negative Doppler shifts in the morning sector of radio aurora, Planet. Space Sci., 27, 233-241, 1979.

Hargreaves, J. K., H. J. A. Chivers, and E. Nielsen, Properties of spike events in auroral radio absorption, J. Geophys. Res., 84, 4245-4250, 1979.

Keys, J. G. and P. V. Johnston, Radio aurora dynamics as seen by Doppler radar, Geophys. Res. Lett., 6, 97-101, 1979.

Moorcroft, D. R. and R. T. Tsunoda, Rapid scan Doppler velocity maps of the UHF diffuse radar aurora, J. Geophys. Res., 83, 1482-1492, 1978.

Ranta, H., The onset of an auroral absorption substorm, J. Geophys. Res., 83, 3893-3899, 1978.

SiRen, J. C., J. R. DoupNIK, and W. L. ECKLUND, A comparison of auroral currents measured by the Chatanika radar with $50-\mathrm{MHz}$ backscatter observed from Anchorage, J. Geophys. Res., 82, 3577-3584, 1977.

Unwin, R. S., T. SAITo, and K. Yuмото, Measurement of the drift of auroral radar echoes with the radar auroragraph, Planet. Space Sci., 26, 519-524, 1978.

VondRaK, R. R. and R. D. SeARs, Comparison of incoherent scatter radar and photometric measurements of the energy distribution of auroral electrons, J. Geophys. Res., 83, 1665-1672, 1978.

\section{f. Effects on the thermosphere}

BABCOCK, R. R., Jr. and J. V. Evans, Effects of geomagnetic disturbances on neutral winds and temperatures in the thermosphere observed over Millstone Hill, J. Geophys. Res., 84, 5349$5354,1979$.

Batista, I. S. and M. A. ABdu, Magnetic storm associated delayed sporadic $E$ enhancements in the Brazilian geomagnetic anomaly, J. Geophys. Res., 82, 4777-4783, 1977.

Buonsanto, M. J., M. Mendillo, and J. A. Klobuchar, The ionosphere at $L=4$ : average behavior and the response to geomagnetic storms, Ann. Geophys., 35, 15-28, 1979.

Chimonas, G., Infrasonic waves from auroral arcs, J. Geophys. Res., 82, 3573-3576, 1977.

ECKlund, W. L., B. B. Balsley, and D. A. Carter, A preliminary comparison of $F$ region plasma drifts and $E$ region irregularity drifts in the auroral zone, J. Geophys. Res., 82, 195197, 1977.

Gerard, J.-C. and D. W. Rusch, The auroral ionosphere: Comparison of a time-dependent model with composition measurements, J. Geophys. Res., 84, 4335-4340, 1979.

HARgreaves, J. K. and F. Bagenal, The behavior of the electron content during ionospheric 
storms: A new method of presentation and comments on the positive phase, J. Geophys. Res., 82, 731-733, 1977.

Harp, P. B., J. W. Meriwether, and R. G. Roble, Nighttime thermosphere winds at high latitudes, J. Geophys. Res., 84, 1905-1913, 1979.

Hedin, A. E., P. Bauer, H. G. Mayr, G. R. Carignan, L. H. Brace, H. C. Brinton, A. D. Parks, and D. T. Pelz, Observations of neutral composition and related ionospheric variations during a magnetic storm in February 1974, J. Geophys. Res., 82, 3183-3189, 1977.

HunsuCKer, R. D., Estimate of the relative importance of Joule heating and the Lorentz force in generating atmospheric gravity waves from the auroral electrojet, J. Geophys. Res., 82, 48264828, 1977.

JACChIA, L. G., J. W. SLOWEy, and U. von ZAHN, Temperature, density and composition in the disturbed thermosphere from Esro 4 gas analyzer measurements: A global match, J. Geophys. Res., 82, 684-688, 1977.

PröLSs, G. W., Seasonal variations of atmospheric-ionospheric disturbances, J. Geophys. Res., 82, 1635-1640, 1977.

Pushkova, G. N. and L. A. Yudovich, Ionsopheric effects of magnetospheric substorms at night, Geomagn. Aeron., 18, 177-179, 1978.

ReEs, M. H. and R. G. Roble, The morphology of N and NO in auroral substorms, Planet. Space Sci., 27, 453-462, 1979.

Richmond, A. D., Thermospheric heating in a magnetic storm: Dynamic transport of energy from high to low latitudes, J. Geophys. Res., 84, 5259-5266, 1979.

Rino, C. L., A. BREKKe, and M. J. BARON, High-resolution auroral zone $E$ region neutral wind and current measurements by incoherent scatter radar, J. Geophys. Res., 82, 2295-2304, 1977.

Roble, M. R. and J. M. GARY, The effect of horizontal transport on auroral NO densities, Geophys. Res. Lett., 6, 703-706, 1979.

Roble, R. G. and M. H. Rees, Time-dependent studies of the aurora: effects of particle precipitation on the dynamic morphology of ionospheric and atmospheric properties, Planet. Space Sci., 25, 991-1010, 1977.

Roble, R. G., R. E. Dickinson, E. C. Ridley, and Y. Kamide, Thermospheric response to the November 8-9, 1969, magnetic disturbances, J. Geophys. Res., 84, 4207-4216, 1979.

Roble, R. G., A. D. Richmond, W. L. Oliver, and R. M. Harper, Ionospheric effects of the gravity wave launched by the September 18, 1974, sudden commencement, J. Geophys. Res., 83, 999-1009, 1978.

Straus, J. M., Dynamics of the thermosphere at high latitudes, Rev. Geophys. Space Phys., 16, 183-194, 1978.

TAEUSCH, D. R., Structure of electrodynamic and particle heating in the disturbed polar thermosphere, J. Geophys. Res., 82, 455-460, 1977.

Torr, M. R. and D. G. TorR, Energetic oxygen: A direct coupling mechanism between the magnetosphere and the ionosphere, Geophys. Res. Lett., 6, 700-702, 1979. 